\title{
The petrogenesis of granitoid rocks unusually rich in apatite in the Western Tatra Mts. (S-Poland, Western Carpathians)
}

\author{
Krzysztof Szopa • Aleksandra Gawęda • Axel Müller • \\ Magdalena Sikorska
}

Received: 27 August 2011 / Accepted: 5 December 2012 /Published online: 3 January 2013

(C) The Author(s) 2012. This article is published with open access at Springerlink.com

\begin{abstract}
In the bottom part of the tongue-shaped, layered granitoid intrusion, exposed in the Western Tatra Mts., apatite-rich granitic rocks occur as pseudo-layers and pockets between I-type hybrid mafic precursors and homogeneous S-type felsic granitoids. The apatite-rich rocks are peraluminous (ASI $=1.12-1.61$ ), with $\mathrm{P}_{2} \mathrm{O}_{5}$ contents ranging from 0.05 to $3.41 \mathrm{wt} . \%$ ( $<7.5$ vol.\% apatite), shoshonitic to high-K calcalkaline. Apatite is present as long-prismatic zoned crystals $\left(\mathrm{Ap}_{1}\right)$ and as large xenomorphic unzoned crystals $\left(\mathrm{Ap}_{2}\right)$. $\mathrm{Ap}_{1}$ apatite and biotite represent an early cumulate. Feldspar and $\mathrm{Ap}_{2}$ textural relations may reflect the interaction of the crystal faces of both minerals and support a model based on local saturation of $(\mathrm{P}, \mathrm{Ca}, \mathrm{F})$ versus $(\mathrm{K}, \mathrm{Na}, \mathrm{Al}, \mathrm{Si}, \mathrm{Ba})$ in the border zones. Chondrite-normalized REE patterns for the apatite rocks and for pure apatite suggest apatite was a main REE carrier in these rocks. Minerals characteristics and the whole rock chemistry suggest both reduced S-type and I-type magma influenced the apatite-rich rocks. The field observations, mineral and rock chemistry as well as mass-balance calculations point out that the presence of apatite-rich rocks may be linked to the continuous mixing of felsic and mafic magmas, creating unique phosphorus- and aluminium-rich magma portions. Formation of these rocks was initially dominated by the complex flowagecontrolled and to some extent also gravity-driven separation of
\end{abstract}

Editorial handling: A. Möller

K. Szopa $(\bowtie) \cdot$ A. Gawęda

Faculty of Earth Sciences, University of Silesia, ul. Będzińska 60, 41-200 Sonowiec, Poland

e-mail: kszopa@us.edu.pl

\section{A. Müller}

Geological Survey of Norway (NGU), Leiv Eirikssons vei 39, 7040 Trondheim, Norway

M. Sikorska

Polish Geological Institute, Rakowiecka 4,

Warsaw, Poland early-formed zoned minerals and, subsequently, by local saturation in the border zones of growing feldspar and apatite crystals. Slow diffusion in the phosphorus-rich magma pockets favoured the local saturation and simultaneous crystallization of apatite and feldspars in a crystal-ladden melt.

\section{Introduction}

Apatite $\mathrm{Ca}_{5}\left[\mathrm{PO}_{4}\right]_{3}(\mathrm{Cl}, \mathrm{OH}, \mathrm{F})$ is a common accessory miner$\mathrm{al}$ in granitoid rocks of different chemistry and provenance. Due to its structural tolerance for substitutions, it is an important carrier of many trace elements, especially incompatible elements (Sha and Chappell 1999). Recent studies indicate that apatite could essentially control the budget of yttrium and LREE in granitoid rocks (Dawson and Hinton 2003; Dempster et al. 2003; Prowatke and Klemme 2006). Accessory apatite, in its chemical zoning, records the crystallization history of the host the magma (Dempster et al. 2003). It is also an indicator of granite petrogenesis, especially important in distinguishing of I- and S-type granites (Sha and Chappell 1999).

Magma phosphorus contents, typically ranging from 0.01 to 0.40 wt.\%, strongly influence phase relations, liquidus and solidus temperatures and affect viscosity and density. Together with volatiles such as water, fluorine and chlorine, it occurs in the apatite structure in varying proportions (Harrison and Watson 1984; Watson and Capobianco 1981). Crystal sizes are usually small and range from some microns to $\mathrm{mm}$. Apatite contents rarely exceed 1 vol.\% of magmatic rock. Unusual host rocks in which it does, are mantle related within-plate intrusions, i.e., carbonatites, alkaline ultramafic rocks, nepheline syenites, nelsonites, gabbro-norites, trachytic volcanics, nevoites and ladogites (Eklund et al. 1998; Dymek and Owens 2001; Belousova et al. 2002). In the rare cases where enhanced apatite contents and phosphorus concentrations in 
granitoids are encountered, they are the results of hybridization with mantle-derived melts affected by carbonate metasomatism (e.g., Eklund et al. 1998) or the formation of magmatic cumulates due to accumulation of early-formed crystals in relatively low viscosity-, water- and fluorine-rich magma (Dorais et al. 1997; Gawęda 2008; Duchesne et al. 2010).

This study investigated unusual apatite-rich granitoids with apatite contents $<7.5$ vol. $\%$ in the granitoid intrusion exposed in the Western Tatra Mts (Fig. 1). The rocks occur at the bottom of a tongue-shaped granitoid pluton formed by multiple injections of magma of different chemistry and origin (Kohut and Janak 1994; Gawęda 2009; Burda et al. 2011; Gaweda and Szopa 2011) in the northern slopes of Starorobociański Mt. (Fig. 2). The exposed section provides an excellent opportunity to study the unusual lithologies formed at the contact of different magma batches. Such rocks have not been mentioned before from this area and have been rarely described elsewhere (e.g. Dorais et al. 1997; Gawęda 2008). They are not only a petrological curiosity, but their study could contribute to a better understanding of granite petrogenesis. The aim of the presented study is to understand the origin and evolution of the apatite-rich granitoid segregations on the basis of their mineralogy and chemistry, and the chemistry of the apatite and of co-genetic minerals. Possible mechanisms of apatite enrichment and possible links of these unusual granitoids to both I-type quartz-diorites and S-type granites from the Western Tatra Mts. are discussed. The unusual mineralogy, textures and geological position of these rocks create the opportunity to discuss the processes acting during magma mixing and storage, influencing the formation of granitoid intrusions and their geotectonic classifications as well as formation of magmatic textures.

\section{Geological setting}

The Tatra Mountains massif, one of the so-called core mountains in the Western Carpathian chain (Fig. 1a), comprises a crystalline core partly covered by Mesozoic sedimentary rocks forming Alpine nappe structures. The crystalline core comprises a Variscan poligenetic granitoid intrusion and its metamorphic envelope (Fig. 1b; Morozewicz 1914; Kohut and Janak 1994). The metamorphic envelope is exposed in the western part of the massif and is strongly migmatized (Burda and Gaweeda 2009; Fig. 1b). The tabular syntectonic granitoid pluton is composed of several magma batches that differ in chemistry. In the Western Tatra Mts., an EarlyVariscan hybridization episode is imprinted on I-type quartzdiorite precursors, occurring as sills in the metamorphic envelope and at the bottom of a granodiorite-tonalite intrusion (Gawęda et al. 2005). The mingling-mixing processes between the granodioritic common Tatra type and quartzdiorite precursors were dated at $368 \pm 8$ Ma by zircon $\mathrm{U}-\mathrm{Pb}$ method (Burda et al. 2011).

In the eastern part of the crystalline core - High Tatra Mts - syenogranite-monzogranite prevail. Main feature of the Tatra granitoid intrusion is the pronounced magmatic layering, K-feldspar rich cumulates, magmatic breccias and structures similar to graded bedding, cross-bedding, troughs and flame structures. The processes, which are suggested to operate during formation of the granitoid body, are: gravitycontrolled separation, magma flow segregation, deposition on the magma-chamber floor, filter pressing and density currents stimulated by tectonic activity (Gawęda and Szopa 2011). High Tatra granitoids are locally strongly enriched in mafic microgranular enclaves (MME) and metamorphic xenoliths (Gawęda 2009 and references therein) and were emplaced between 361 and $345 \mathrm{Ma}$ ago as dated by zircon $\mathrm{U}-\mathrm{Pb}$ method (Gawęda 2008) as numerous magma injections representing different stages in the mixing and mingling of felsic and mafic sources. All these granitoid pulses show geochemical and isotopic signatures suggesting that the granitoid melts were produced by melting of heterogeneous metasediments during subduction of oceanic crust under the continental wedge and by interaction with mantle derivatives (Broska and Uher 2001; Gawęda 2009; Burda et al. 2011).
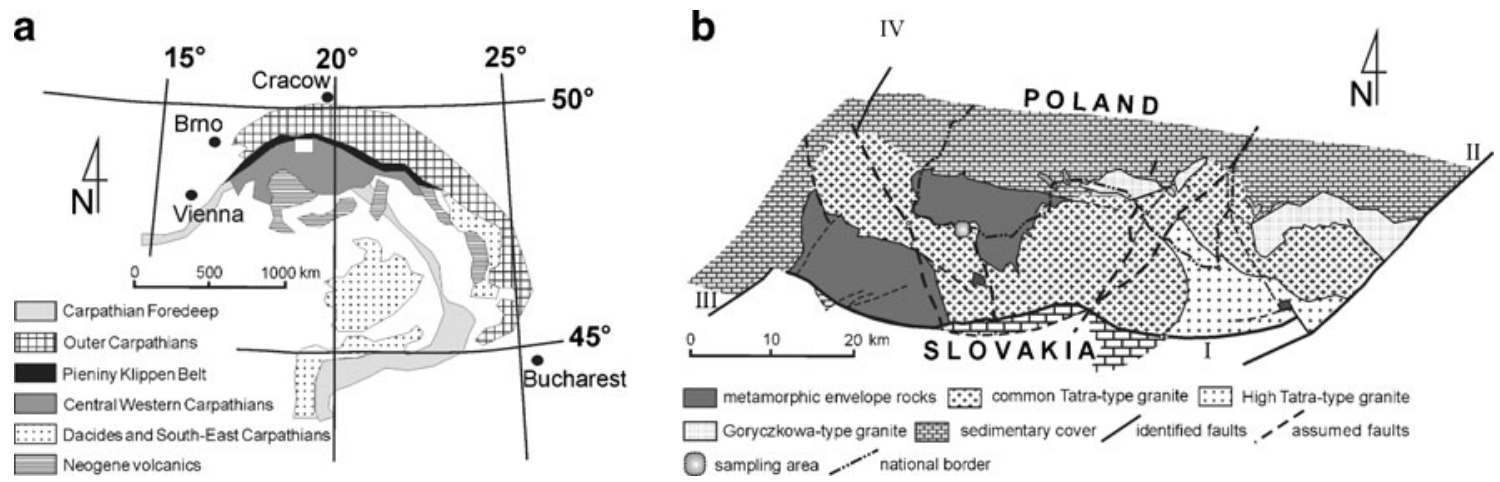

Fig. 1 The geology of the Tatra Mts. a Simplified geological sketch of the Carpathian chain. b Geological map of the Tatra Mts. massif according to Kohut and Janak (1994), Bac-Moszaszwili (1996) and Gawęda (2009). Grey square indicates the location of the section shown in Fig. 2 


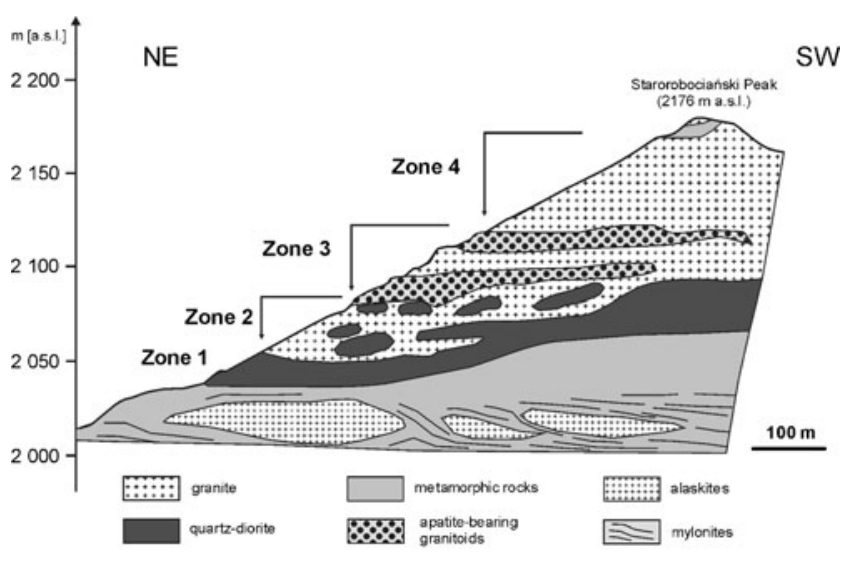

Fig. 2 Geological section of the northern slope of Starorobociański peak (sampling area)

The present structure of the Tatra Massif reflects brittle tectonics related to Paleogene uplift of the massif and its division into small tectonic blocks at 36-28 Ma and at 20$10 \mathrm{Ma}$ as revealed by fission tracks and ${ }^{40} \mathrm{Ar}-{ }^{39} \mathrm{Ar}$ dating (Burchart 1972; Kohut and Sherlock 2003). In the Quaternary, the massif and its Alpine sedimentary cover was tilted to the north along the currently active Sub-Tatric Fault (Fig. 1b).

\section{Sampling and analytical techniques}

\section{Sampling}

In the profile of the Starorobociański Wierch in the Western Tatra Mts, the bottom of the tongue-shaped Western Tatra Mountains granitoid intrusion crops out (Figs. $1 \mathrm{~b}$ and 2). In this profile, the $2-5 \mathrm{~m}$ thick horizons of granitic rocks extremely enriched in apatite occur above a mixingmingling zone of granite and diorite - quartz-diorite (mafic precursors; Gawęda et al. 2005; Burda et al. 2011). The profile comprises a lowermost Zone 1 of diorite - quartzdiorite, showing transitional contact to an intermediate Zone 2 of granitoid rocks characterized by magma mingling textures, dated at $368 \mathrm{Ma}$ by zircon U-Pb method (Burda et al. 2011), a cumulative apatite-enriched rocks in Zone 3, showing sharp contacts to Zone 2 and transitional contact with the uppermost Zone 4, comprising equigranular monzogranite and pophyritic K-feldspar-rich granite, locally with metapelitic xenoliths (Fig. 2). Samples weighting 2-5 kg each were collected from the profile.

Microscopy and whole rock analysis

Microscopic examination of 28 polished standard thin sections covering the zones of apatite enrichment (Zone 3) was carried out to select samples for further chemical and micro- chemical investigation. This initial work involved use of a BX-51 Olympus microscope at the Faculty of Earth Sciences, University of Silesia, Poland. Whole-rock samples were analysed by XRF for major and LILE trace elements and by ICP-MS for HFSE and REE at the ACME Analytical Laboratories, Vancouver, Canada, using sets of internationally recognized standards, according to procedures described on http://acmelab.com. REE of rocks and apatite were normalized to $\mathrm{C} 1$ chondrite (Sun and McDonough 1989). Data from an apatite-rich enclave in the High Tatra granite (Gawęda 2008) was used for comparison.

Electron probe micro analysis (EPMA)

Microprobe analyses and BSE imaging of apatite, alkali feldspars, plagioclase and biotite were carried out on a CAMECA SX-100 electron microprobe in the InterInstitution Laboratory of Microanalysis of Minerals and Synthetic Substances, Warsaw. Analytical conditions were $10 \mathrm{~s}$ counting time per element, $15 \mathrm{kV}$ accelerating voltage and $20 \mathrm{nA}$ beam current. Sets of natural and synthetic standards were used for calibration.

The apatite analyses have been normalized to the sum of 50 negative charges including 24 oxygen ions and two monovalent anions (fluorine site), according to the ideal chemical formula of apatite-(CaF): $\mathrm{A}_{10}\left(\mathrm{BO}_{4}\right)_{6}(\mathrm{X})_{2}$ where site $\mathrm{A}$ is occupied by $\mathrm{Ca}, \mathrm{Fe}, \mathrm{Mn}, \mathrm{Mg}$, Th, REE, $\mathrm{Y}$ and $\mathrm{Na}$, site $\mathrm{B}$ by $\mathrm{P}$ (substituted by $\mathrm{S}, \mathrm{Si}$ ) and site $\mathrm{X}$ by $\mathrm{F}, \mathrm{Cl}$ and $\mathrm{OH}$ group.

\section{Cathodoluminescence (CL)}

Cathodoluminescence (CL) images of apatites and feldspars were obtained using a CCL $8200 \mathrm{mk} 3$ apparatus (Cambridge Image Technology Ltd.) mounted on an Optiphot 2 Nikon microscope, using conventional photography (Fuji 1600 ASA film). The applied accelerating voltage was $20 \mathrm{kV}$, the beam current $500 \mathrm{~mA}$ and the vacuum $0.5-0.2$ Torr. CL spectra in the range of $0-1000 \mathrm{~nm}$ were collected on a SEM-CL VIS-View 900 (SIM GmbH) with monochromator Zeiss-VIS in the Polish Geological Institute, Warsaw, Poland.

Laser-ablation inductively coupled plasma mass spectrometry (LA-ICP-MS)

REE, Sr, Y, $\mathrm{P}$ and $\mathrm{Ca}$ were analysed in 57 apatite grains, mounted in a casting form, using the LA-ICP-MS at the Geological Survey of Norway, Trondheim. LA-ICP-MS was applied for the in situ determination of $\mathrm{Ca}^{44}, \mathrm{Sr}^{86}, \mathrm{Y}^{89}$, $\mathrm{La}^{139}, \mathrm{Ce}^{140}, \mathrm{Pr}^{141}, \mathrm{Nd}^{144}, \mathrm{Sm}^{152}, \mathrm{Eu}^{151}, \mathrm{Gd}^{158}, \mathrm{~Tb}^{159}$, $\mathrm{Dy}^{163}, \mathrm{Ho}^{165}, \mathrm{Er}^{167}, \mathrm{Tm}^{169}, \mathrm{Yb}^{171}$ and $\mathrm{Lu}^{175}$ in apatite. The ICP-MS used in this study is a double focusing sector 
Table 1 Operating parameters of the ICP-MS and key method parameters

$\begin{array}{ll}\text { Laser parameters } & \\ \text { Wavelength } & 193 \mathrm{~nm} \\ \text { Pulse width } & <5 \mathrm{~ns} \\ \text { Irradiance (power density) } & 1.64 \mathrm{GW} / \mathrm{cm}^{2} \\ \text { Fluence (energy density) } & 8.21 \mathrm{~J} / \mathrm{cm}^{2} \\ \text { Spot size } & 50 \mu \mathrm{m} \\ \text { Laser repetition rate/pulse rate } & 10 \mathrm{~Hz} \\ \text { Sample helium flow rate } & 0.7 \mathrm{l} / \mathrm{min} \\ \text { ICP-MS parameters } & \\ \text { Plasma power } & 974-1100 \mathrm{~W} \\ \text { Auxiliary gas flow } & 1.07-1.2 \mathrm{l} / \mathrm{min} \\ \text { Sample gas flow } & 0.9-1.1 \mathrm{l} / \mathrm{min} \\ \text { Cone } & \text { High performance Ni } \\ \text { CD-2 guard electrode } & \text { Yes } \\ \text { Data collection } & \\ \text { SCAN type } & \text { E-scan } \\ \text { No. of scans } & 15 \\ \text { Mass range at low mass resolution (LR) } & 20 \% \text { of isotope peak } \\ \text { Samples per peak at low mass resolution (LR) } & 60 \\ \text { Segment duration (analysis time per isotope } & 0.024 \mathrm{~s} \\ \text { per scan) at low mass resolution (LR) } & \end{array}$
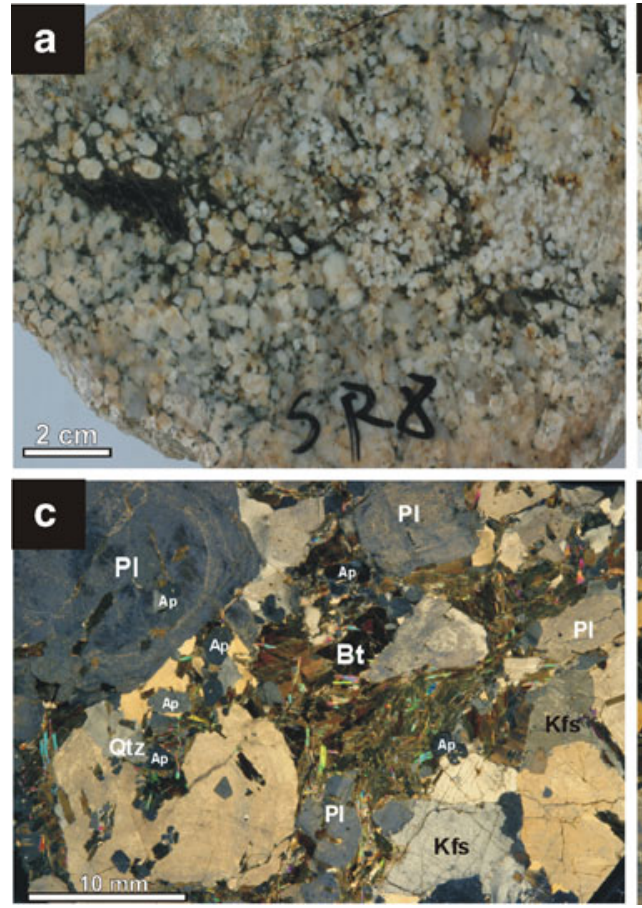

Fig. 3 Photographs of the investigated samples. a Photograph of the cumulative granitoid rock (SR8) composed of feldspars (locally zoning visible), quartz, biotite and apatite. Size gradation of feldspar phenocrysts from the bottom to the top could be noted. b Photograph of the cumulative granitoid rocks (Sample SR 9), with feldspar-dominated framework. c Microphotograph of the cumulative granitoid rock (SR 8) composed of plagioclase (Pl), quartz (Qtz), K-feldspar (Kfs), biotite field instrument (model-ELEMENT-1, Finnigan MAT) combined with a New Wave UP-193-nm excimer laser probe. Continuous raster ablation was carried out using a repetition rate of $10 \mathrm{~Hz}$, a spot size of $50 \mu \mathrm{m}$, a laser speed of $10 \mu \mathrm{m} / \mathrm{s}$ and pulse energy of $16.4 \mathrm{~mJ}$. The applied laser conditions resulted in an ablated area of approximately $150 \times 100 \mu \mathrm{m}$.

External calibration was done using four silicate glass reference materials produced by the National Institute of Standards and Technology (NIST SRM 610, NIST SRM 612, NIST SRM 614, NIST SRM 616). In addition, the USGS reference materials BHVO-2G basalt glass was used. Each measurement consisted of 15 scans of each isotope, with a measurement time of $0.024 \mathrm{~s}$ per scan in the low resolution modus. An Ar-blank was run before each standard and sample measurement. The $\mathrm{Ca}^{44}$ isotope was applied as an internal standard. The $\mathrm{Ca}$ and $\mathrm{P}$ concentrations of the apatites were determined by microprobe prior to the LAICP-MS analyses, excluding the presence of $\mathrm{C}$ in the apatite. The background signal was subtracted from the instrumental response of the standard before normalisation against the internal standard. This was done to avoid memory effects between samples. A weighted linear regression model including several measurements of the different standards was
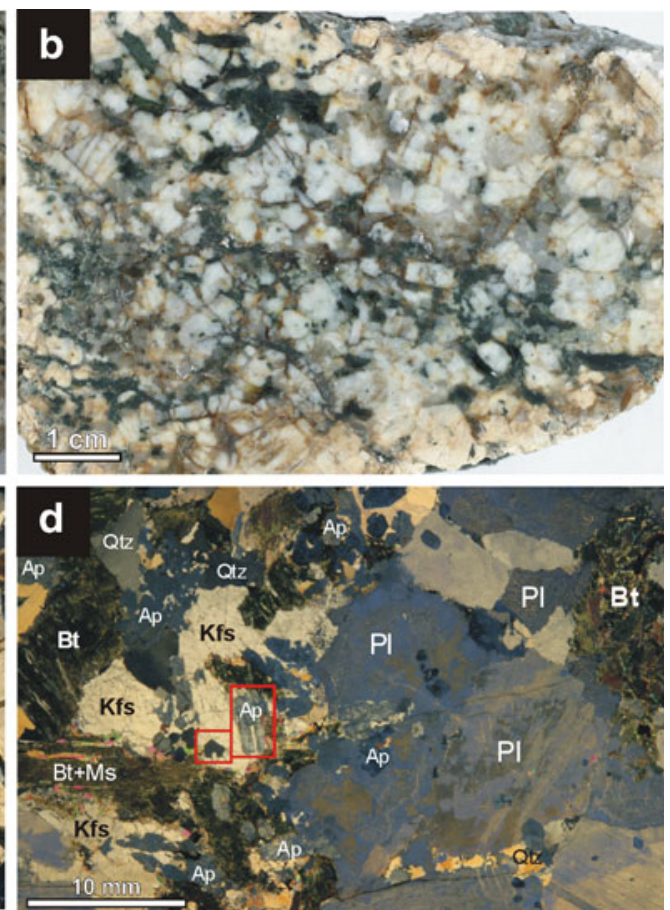

$(\mathrm{Bt})$ and apatite $(\mathrm{Ap})$. Note the biotite and apatite $\left(\mathrm{Ap}_{1}\right)$ concentration between the feldspar-dominated network. Crossed nicols. d Microphotograph of the cumulative granitoid rock (SR9) with abundant xenomorphic apatite $\left(\mathrm{Ap}_{2}\right)$, intergrown with feldspars. Apatite crystals presented on the Fig. 5 are marked by red rectangles. $K f s$ K-feldspar, $P l$ plagioclase, $B t$ biotite, $Q t z$ quartz 
Table 2 Chemical composition and crystal-chemical formulae $\left(22 \mathrm{O}^{2-}\right)$ of biotite types from apatite-rich granitoid rocks from the Western Tatra Mts

\begin{tabular}{|c|c|c|c|}
\hline & 1 & 2 & 3 \\
\hline $\mathrm{SiO}_{2}$ (wt. \%) & 34.95 & 34.86 & 34.89 \\
\hline $\mathrm{TiO}_{2}$ & 2.60 & 2.69 & 2.83 \\
\hline $\mathrm{Al}_{2} \mathrm{O}_{3}$ & 17.90 & 17.50 & 17.44 \\
\hline $\mathrm{Cr}_{2} \mathrm{O}_{3}$ & 0.03 & 0.05 & 0.02 \\
\hline $\mathrm{MgO}$ & 8.40 & 8.62 & 8.63 \\
\hline $\mathrm{CaO}$ & 0.00 & 0.01 & 0.00 \\
\hline $\mathrm{MnO}$ & 0.32 & 0.40 & 0.38 \\
\hline $\mathrm{FeO}$ & 20.64 & 20.88 & 20.34 \\
\hline $\mathrm{Na}_{2} \mathrm{O}$ & 0.13 & 0.12 & 0.13 \\
\hline $\mathrm{K}_{2} \mathrm{O}$ & 9.50 & 9.71 & 9.63 \\
\hline $\mathrm{H}_{2} \mathrm{O}$ & 3.86 & 3.86 & 3.85 \\
\hline Total & 98.33 & 98.69 & 98.14 \\
\hline $\mathrm{Si}(a p f u)$ & 5.42 & 5.41 & 5.43 \\
\hline $\mathrm{Al}^{\mathrm{IV}}$ & 3.28 & 3.20 & 3.20 \\
\hline $\mathrm{Al}^{\mathrm{VI}}$ & 0.58 & 0.59 & 0.57 \\
\hline $\mathrm{Ti}$ & 0.30 & 0.31 & 0.33 \\
\hline $\mathrm{Cr}$ & 0.00 & 0.01 & 0.00 \\
\hline $\mathrm{Fe}$ & 2.68 & 2.71 & 2.65 \\
\hline $\mathrm{Mg}$ & 1.94 & 2.00 & 2.00 \\
\hline $\mathrm{Ca}$ & 0.00 & 0.00 & 0.00 \\
\hline $\mathrm{Mn}$ & 0.04 & 0.05 & 0.05 \\
\hline $\mathrm{Na}$ & 0.04 & 0.03 & 0.04 \\
\hline $\mathrm{K}$ & 1.88 & 1.92 & 1.91 \\
\hline$f m$ & 0.58 & 0.58 & 0.57 \\
\hline
\end{tabular}

applied for calculation of the calibration curve for each element to estimate the limits of detection (LOD). LOD are based on $3 \times$ standard deviation $(3 \sigma)$ of 10 measurements divided by the sensitivity. The analytical error ranges within
$10 \%$ of the absolute concentration of the elements. All details of the LA-ICP-MS parameters are shown in Table 1.

\section{Petrography}

Granitoid rocks with anomalously high apatite contents occur in Zone 3 and are composed of alkali feldspar, plagioclase, quartz and apatite as rock-forming minerals. Biotite (partially chloritized) is present in the interstices (Fig. 3a and c). Accessory phases are muscovite, zircon, secondary chlorite, titanite, epidote, (as products of biotite alteration), pyrite (locally replaced by $\mathrm{Fe}$ oxides and hydroxides) and rare monazite (in one sample only). The rocks show cumulative fabric (Fig. 3a, b, c and d) comprising closely packed zoned feldspar phenocrysts $0.3-2 \mathrm{~cm}$ in size, with zoning visible both macroscopically (Fig. 3a and b), and microscopically (Fig. 3c and d) and apatite with quartz and biotite filling the interstices. Two different types of biotite could be distinguished on the basis of their chemistry: $\mathrm{Bt}_{1}$ with $f m=\mathrm{Fe}_{\mathrm{T}} /\left(\mathrm{Fe}_{\mathrm{T}}+\mathrm{Mg}+\mathrm{Mn}\right)=0.40-0.48$ and $\mathrm{Bt}_{2}$ with $f m=0.56-0.57$ (Table 2), both unzoned. Plagioclases are represented by zoned albite-oligoclase $\mathrm{An}_{8-19}$ to $\mathrm{An}_{1-4}$ while K-feldspars show inverted chemical zonation, with $\mathrm{BaO}$ concentration growing from $0.27 \mathrm{wt} . \%$ in the core to $1.45 \mathrm{wt} . \%$ at the margin (Table 3 ). Primary magmatic minerals show ductile and brittle deformations locally.

In the analysed rocks, apatite- $(\mathrm{Ca}, \mathrm{F})$ is one of the main rock-forming minerals. Long-prismatic, idiomorphic, usually zoned apatite crystals, $100-500 \mu \mathrm{m}$ in length, represent the first morphological type $\left(\mathrm{Ap}_{1}\right)$. They occur mostly as inclusions in plagioclase, both irregularly distributed (Figs. $4 \mathrm{a}$ and $5 \mathrm{~b}$ ) and elongated according to crystal faces (Fig. 5b) or packed in the feldspar interstices, together with
Table 3 Chemical composition and crystal-chemical formulae $\left(8 \mathrm{O}^{2-}\right)$ of feldspars from apatite-rich granitoids

\begin{tabular}{|c|c|c|c|c|c|c|c|c|}
\hline & \multicolumn{3}{|c|}{ Plagioclase } & \multicolumn{5}{|c|}{ Alkali feldspar } \\
\hline & P1 1 & P1 3 & P1 9 & Afs 1 & Afs 3 & Afs 4 & Afs 37 & Afs 45 \\
\hline $\mathrm{SiO}_{2}$ (wt. \%) & 66.65 & 66.20 & 63.47 & 64.08 & 64.20 & 63.94 & 65.01 & 64.95 \\
\hline $\mathrm{Al}_{2} \mathrm{O}_{3}$ & 20.68 & 21.66 & 22.75 & 18.71 & 18.57 & 18.70 & 18.45 & 18.25 \\
\hline $\mathrm{MgO}$ & 0.01 & 0.04 & 0.00 & 0.00 & 0.01 & 0.01 & 0.00 & 0.00 \\
\hline $\mathrm{CaO}$ & 1.86 & 0.53 & 3.97 & 0.00 & 0.00 & 0.04 & 0.05 & 0.02 \\
\hline $\mathrm{FeO}$ & 0.00 & 0.07 & 0.04 & 0.00 & 0.04 & 0.09 & 0.05 & 0.04 \\
\hline $\mathrm{BaO}$ & 0.00 & 0.00 & 0.00 & 1.45 & 1.43 & 1.25 & 0.47 & 0.27 \\
\hline $\mathrm{Na}_{2} \mathrm{O}$ & 10.50 & 10.02 & 9.02 & 0.46 & 1.05 & 0.80 & 0.69 & 0.45 \\
\hline $\mathrm{K}_{2} \mathrm{O}$ & 0.19 & 1.25 & 0.25 & 15.47 & 14.74 & 14.93 & 15.44 & 15.75 \\
\hline Total & 99.88 & 99.78 & 99.50 & 100.16 & 100.04 & 99.75 & 100.14 & 99.73 \\
\hline $\mathrm{Ab}$ & 90.12 & 89.99 & 79.26 & 4.16 & 9.47 & 7.13 & 6.33 & 4.10 \\
\hline Or & 1.11 & 7.38 & 1.43 & 93.20 & 87.91 & 90.32 & 92.65 & 95.38 \\
\hline Cs & 0.00 & 0.00 & 0.00 & 2.64 & 2.62 & 2.34 & 0.82 & 0.51 \\
\hline An & 8.77 & 2.63 & 19.31 & 0.00 & 0.00 & 0.20 & 0.20 & 0.00 \\
\hline
\end{tabular}


partly chloritized biotite and quartz (Fig. 4b). The crystals are characterized by elongation ratios ranging from $4: 1$ to 8:1 and reveal internal zoning in optical and luminescence images (Figs. 4d and 5a). Xenomorphic, irregular to subidiomorphic apatite- $(\mathrm{Ca}, \mathrm{F})$ crystals $\left(\mathrm{Ap}_{2}\right)$ represent more than 80 vol. $\%$ of the total apatite population. They are present as inclusions in K-feldspar and plagioclase phenocrysts (Figs. 3c, d and 4c) and show a weak chemical zonation or none at all (Fig. 5c, d, e and f).

\section{Rock geochemistry}

The apatite-rich granitoids are peraluminous with aluminium saturation indices (ASI) in the range of 1.12-1.61 and phosphorus content ranging from 0.05 to $3.41 \mathrm{wt} \%$. The $\mathrm{Na}_{2} \mathrm{O} / \mathrm{K}_{2} \mathrm{O}$ ratio varies from 0.47 to 2.74 (Table 4). The high potassium content, together with the low $\mathrm{TiO}_{2}$ allow these rocks to be classified as shoshonitic to high K-calc-alkaline according to Peccerillo and Taylor (1976; Table 4).

Both $\mathrm{P}_{2} \mathrm{O}_{5}$ and $\mathrm{CaO}$ are negatively correlated versus $\mathrm{SiO}_{2}$ (Figs $6 \mathrm{a}$ and $\mathrm{b}$ ) and $\mathrm{CaO}$ and $\mathrm{P}_{2} \mathrm{O}_{5}$ show a strong positive correlation (Fig. 6f), indicating that almost all of the $\mathrm{Ca}$ is bound in apatite. $\mathrm{CaO}$ correlates positively with $\mathrm{P}_{2} \mathrm{O}_{5}$ $\left(r^{2}=0.999\right.$; Fig. 6e), what means that apatite is the only $\mathrm{Ca}$ carrier. Samples with the highest phosphorus contents show a predominance of $\mathrm{Nd}$ over $\mathrm{Th}$ and a marked negative correlation of these two elements (Fig. 7). In six apatite-rich samples, $\mathrm{Nd}$ correlates positively with $\mathrm{P}_{2} \mathrm{O}_{5}$ while Th shows a negative
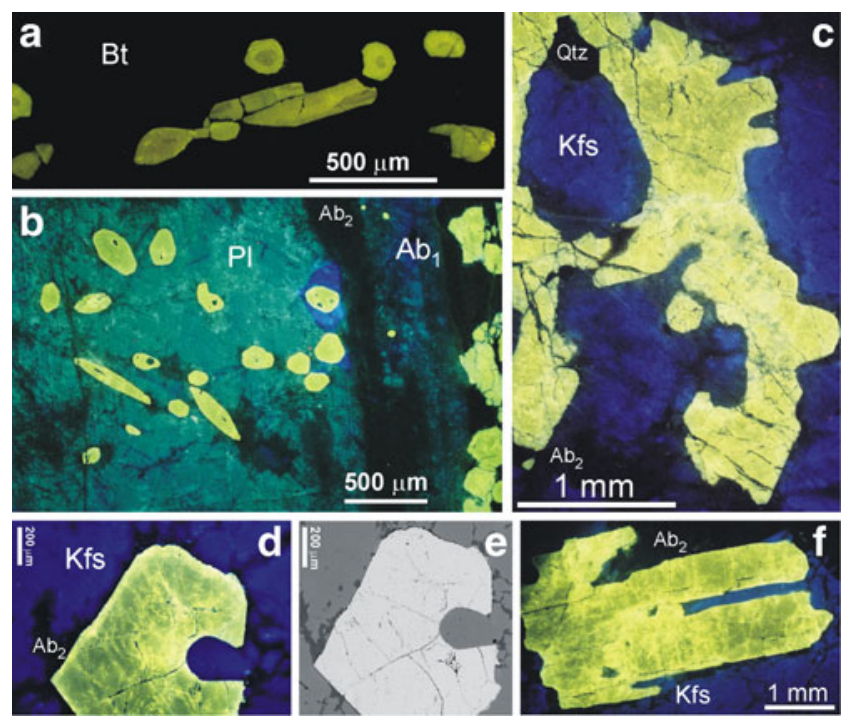

Fig. 5 Cathodoluminescence (CL) and BSE images of the apatite and feldspar crystals from the apatite-rich rocks. a Zoned $\mathrm{Ap}_{1}$ in biotite matrix (black) from sample SR 8. b Zoned plagioclase with abundant apatite inclusions and apatite crystals concentrated along the plagioclase crystal faces (right side of the photo). c Irregular unzoned apatite crystal, intergrown with K-feldspar. d Weak zoning of apatite included in K-feldspar (sample SR9, compare Fig. 3d). e BSE image of the apatite from $e$ ) - note lack of any zoning in apatite and perthitic $\mathrm{Ab}_{2}$ veins (black in Fig. d). f Patchy CL colour distribution in twinned apatite elongated parallel to K-feldspar crystal faces (sample SR9, compare Fig. 3d)

correlation (Figs $6 \mathrm{~g}$ and $\mathrm{h}$ ). In these samples, enrichment in $\mathrm{Y}$ is also evident (Table 4). Local increases in $\mathrm{Ba}$ and $\mathrm{Rb}$ is
Fig. 4 Apatite-feldspars relations in the thin sections. a Microphotograph (PPL) of the plagioclase $(\mathrm{Pl})$ phenocryst with abundant apatite (Ap) inclusions. b Closely packed feldspar framework with zoned apatite $\left(\mathrm{Ap}_{1}\right)$, biotite and quartz in the interstices. $\mathbf{c}$ Irregular apatite $\left(\mathrm{Ap}_{2}\right)$ inclusion in plagioclase. Note the thin $\mathrm{K}$ feldspar coating on the apatite crystal. d Zoned apatite $\left(\mathrm{Ap}_{1}\right)$ crystals showing dark cores, surrounded by chlorite (Chl), $\mathrm{K}$-feldspar and quartz. Compare $\mathrm{CL}$ and chemical features presented on the Fig. 10
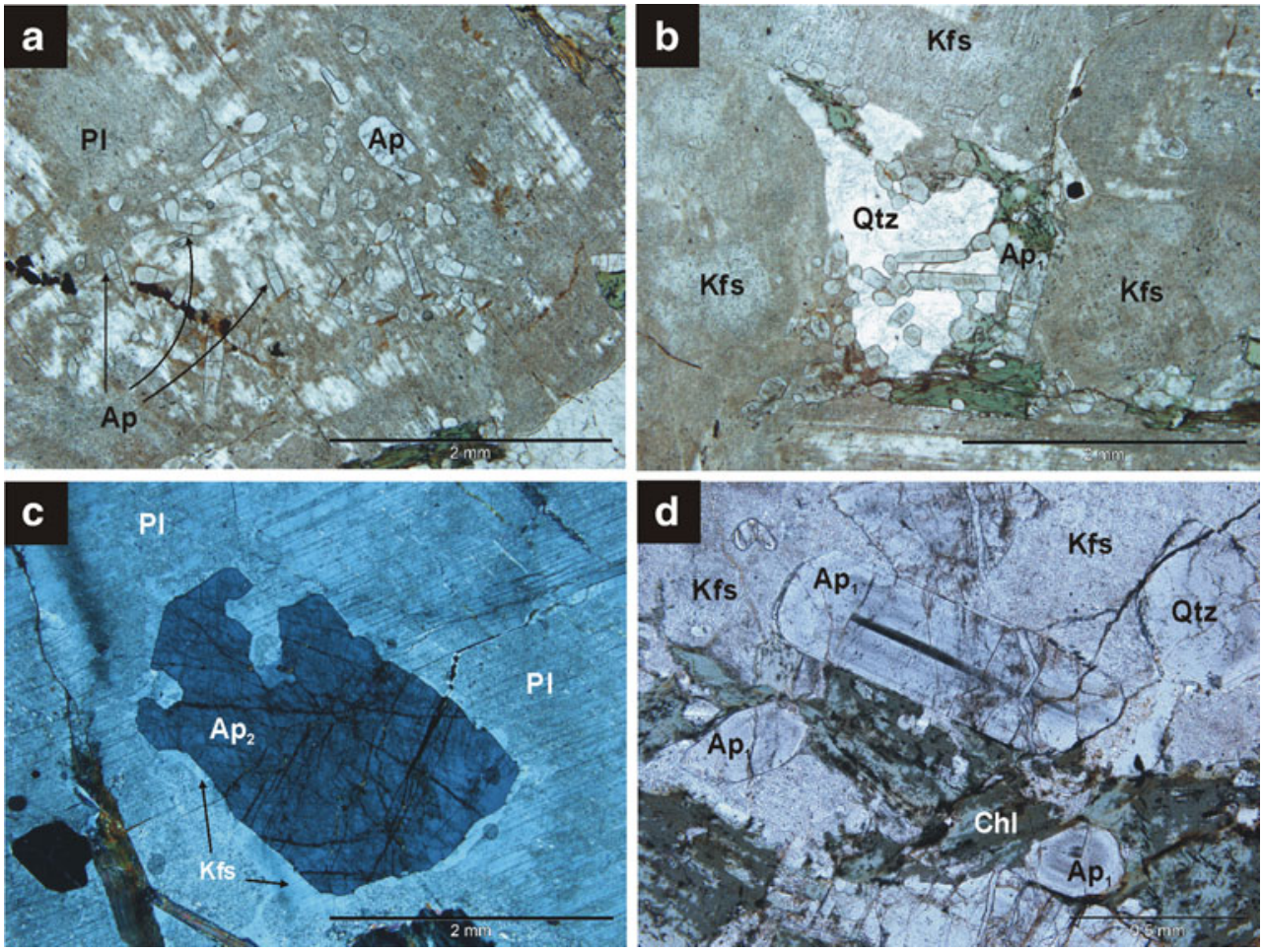
Table 4 Chemical compositions and selected petrological indices for apatite-rich granitoid rocks and associated granites from the Western Tatra Mts. The apatite-rich cumulative enclave (G2) is used as a reference

\begin{tabular}{|c|c|c|c|c|c|c|c|c|}
\hline Sam no. & $\begin{array}{l}\text { ST4 } \\
\text { Cumul }\end{array}$ & $\begin{array}{l}\text { ST5 } \\
\text { Cumul }\end{array}$ & $\begin{array}{l}\text { SR5 } \\
\text { Cumul }\end{array}$ & $\begin{array}{l}\text { SR6 } \\
\text { Cumul }\end{array}$ & $\begin{array}{l}\text { SR7 } \\
\text { Cumul }\end{array}$ & $\begin{array}{l}\text { SR8 } \\
\text { Cumul }\end{array}$ & $\begin{array}{l}\text { SR9 } \\
\text { Cumul }\end{array}$ & $\begin{array}{l}\text { G2 } \\
\text { HT-en }\end{array}$ \\
\hline $\mathrm{SiO}_{2}$ & 62.57 & 72.72 & 54.14 & 73.81 & 63.09 & 68.66 & 58.40 & 48.89 \\
\hline $\mathrm{TiO}_{2}$ & 0.16 & 0.24 & 0.92 & 0.17 & 0.33 & 0.33 & 0.32 & 1.23 \\
\hline $\mathrm{Al}_{2} \mathrm{O}_{3}$ & 18.56 & 14.00 & 18.50 & 14.49 & 18.90 & 15.55 & 18.14 & 16.21 \\
\hline $\mathrm{Fe}_{2} \mathrm{O}_{3 \mathrm{~T}}$ & 1.48 & 1.77 & 7.87 & 0.87 & 2.29 & 2.92 & 2.41 & 7.98 \\
\hline $\mathrm{MnO}$ & 0.04 & 0.03 & 0.13 & 0.03 & 0.06 & 0.06 & 0.09 & 0.11 \\
\hline $\mathrm{MgO}$ & 0.64 & 0.50 & 3.26 & 0.25 & 1.14 & 1.11 & 1.11 & 2.70 \\
\hline $\mathrm{CaO}$ & 1.87 & 0.74 & 3.05 & 0.39 & 2.22 & 0.83 & 4.93 & 7.21 \\
\hline $\mathrm{Na}_{2} \mathrm{O}$ & 4.47 & 2.89 & 4.59 & 3.72 & 4.59 & 4.90 & 6.99 & 1.67 \\
\hline $\mathrm{K}_{2} \mathrm{O}$ & 7.49 & 6.00 & 2.89 & 4.85 & 4.20 & 3.85 & 2.55 & 6.57 \\
\hline $\mathrm{P}_{2} \mathrm{O}_{5}$ & 1.24 & 0.09 & 1.99 & 0.13 & 1.47 & 0.42 & 3.41 & 5.08 \\
\hline LOI & 1.20 & 0.60 & 3.00 & 1.00 & 2.00 & 1.40 & 1.50 & 2.00 \\
\hline Total & 99.72 & 99.58 & 100.34 & 99.71 & 100.29 & 100.03 & 99.85 & 99.65 \\
\hline $\mathrm{Sr}$ & 506.2 & 287.8 & 319.7 & 153.2 & 245.1 & 303.3 & 408.4 & 384.3 \\
\hline $\mathrm{Ba}$ & 1469 & 1863 & 405 & 880 & 552 & 599 & 422 & 2538.5 \\
\hline $\mathrm{Rb}$ & 151.3 & 114.7 & 104.7 & 106.4 & 111.0 & 90.9 & 74.6 & 179.6 \\
\hline Th & 7.1 & 16.5 & 1.9 & 8.2 & 4.1 & 9.7 & 0.3 & 25.1 \\
\hline $\mathrm{U}$ & 2.0 & 2.7 & 5.3 & 2.6 & 4.0 & 2.1 & 6.1 & 8.7 \\
\hline $\mathrm{Ga}$ & 20.5 & 14.6 & 34.6 & 14.5 & 278 & 20.5 & 22.5 & 28.5 \\
\hline $\mathrm{Zr}$ & 143.4 & 144.7 & 157.1 & 77.8 & 62.2 & 103.9 & 8.2 & 440.8 \\
\hline Hf & 1.2 & 4.7 & 5.2 & 2.5 & 2.5 & 3.6 & 0.3 & 13.6 \\
\hline $\mathrm{Y}$ & 9.0 & 9.7 & 79.9 & 18.2 & 70.8 & 18.6 & 125.4 & 401.1 \\
\hline $\mathrm{Nb}$ & 8.4 & 4.9 & 24.0 & 6.7 & 12.4 & 10.7 & 8.8 & 19.7 \\
\hline $\mathrm{Ta}$ & 0.5 & 0.3 & 1.8 & 6.7 & 1.1 & 0.8 & 0.6 & 1.0 \\
\hline $\mathrm{La}$ & 11.0 & 36.2 & 16.9 & 16.5 & 16.9 & 12.5 & 24.1 & 105.5 \\
\hline $\mathrm{Ce}$ & 30.0 & 83.9 & 51.3 & 37.4 & 46.8 & 50.2 & 79.0 & 266.6 \\
\hline $\operatorname{Pr}$ & 4.51 & 9.59 & 7.66 & 4.32 & 6.67 & 3.93 & 11.14 & 36.9 \\
\hline $\mathrm{Nd}$ & 20.3 & 38.0 & 37.0 & 15.7 & 28.9 & 15.2 & 49.9 & 163.8 \\
\hline $\mathrm{Sm}$ & 5.5 & 7.26 & 10.45 & 3.83 & 9.18 & 3.8 & 14.93 & 54.1 \\
\hline $\mathrm{Eu}$ & 1.30 & 1.01 & 1.59 & 0.65 & 1.33 & 0.60 & 2.33 & 6.78 \\
\hline $\mathrm{Gd}$ & 5.59 & 4.70 & 12.03 & 3.51 & 10.55 & 3.50 & 17.02 & 63.48 \\
\hline $\mathrm{Tb}$ & 1.17 & 0.59 & 2.33 & 0.60 & 2.16 & 0.65 & 3.56 & 12.23 \\
\hline Dy & 6.77 & 2.21 & 13.74 & 3.14 & 12.49 & 3.49 & 21.27 & 72.06 \\
\hline Ho & 1.30 & 0.26 & 2.57 & 0.55 & 2.31 & 0.60 & 3.91 & 14.07 \\
\hline Er & 3.68 & 0.68 & 6.95 & 1.49 & 6.19 & 1.62 & 10.63 & 35.49 \\
\hline $\mathrm{Tm}$ & 0.55 & 0.09 & 0.99 & 0.23 & 0.91 & 0.23 & 1.52 & 4.64 \\
\hline $\mathrm{Yb}$ & 3.35 & 0.62 & 6.02 & 1.45 & 5.31 & 1.42 & 9.05 & 23.27 \\
\hline $\mathrm{Lu}$ & 0.45 & 0.08 & 0.79 & 0.21 & 0.72 & 0.2 & 1.18 & 3.00 \\
\hline $\mathrm{F}$ & 980 & 180 & 2040 & 170 & 1240 & 460 & 2230 & nd \\
\hline ASI & 1.168 & 1.121 & 1.614 & 1.231 & 1.498 & 1.221 & 1.204 & 1.499 \\
\hline $\mathrm{Rb} / \mathrm{Sr}$ & 0.299 & 0.399 & 0.327 & 0.695 & 0.453 & 0.299 & 0.183 & 0.467 \\
\hline $\mathrm{Nd} / \mathrm{Th}$ & 2.859 & 2.303 & 19.474 & 1.195 & 7.049 & 1.567 & 166.33 & 6.526 \\
\hline$\Sigma$ REE & 95.47 & 185.19 & 170.32 & 89.58 & 150.42 & 97.94 & 249.54 & 862.12 \\
\hline $\mathrm{Eu} / \mathrm{Eu}^{*}$ & 0.717 & 0.529 & 0.434 & 0.542 & 0.413 & 0.503 & 0.447 & 0.354 \\
\hline $\mathrm{Ce}_{\mathrm{N}} / \mathrm{Yb}_{\mathrm{N}}$ & 2.467 & 37.285 & 2.348 & 7.107 & 2.428 & 9.740 & 2.405 & 3.157 \\
\hline
\end{tabular}

cumul sample of cumulative fabric, $g r$ granitoid, HT-en apatite-rich cumulative enclave (from Gawęda 2008); ASI (aluminium saturation index) = mol. $\mathrm{Al}_{2} \mathrm{O}_{3} /\left(\mathrm{K}_{2} \mathrm{O}+\mathrm{Na}_{2} \mathrm{O}+\mathrm{CaO}-3.33 \mathrm{P}_{2} \mathrm{O}_{5}\right) ; \mathrm{Eu} / \mathrm{Eu}^{*}=\mathrm{Eu}_{\mathrm{N}} /\left(\sqrt{ } \mathrm{Sm}_{\mathrm{N}} \cdot \mathrm{Gd}_{\mathrm{N}}\right)$ 

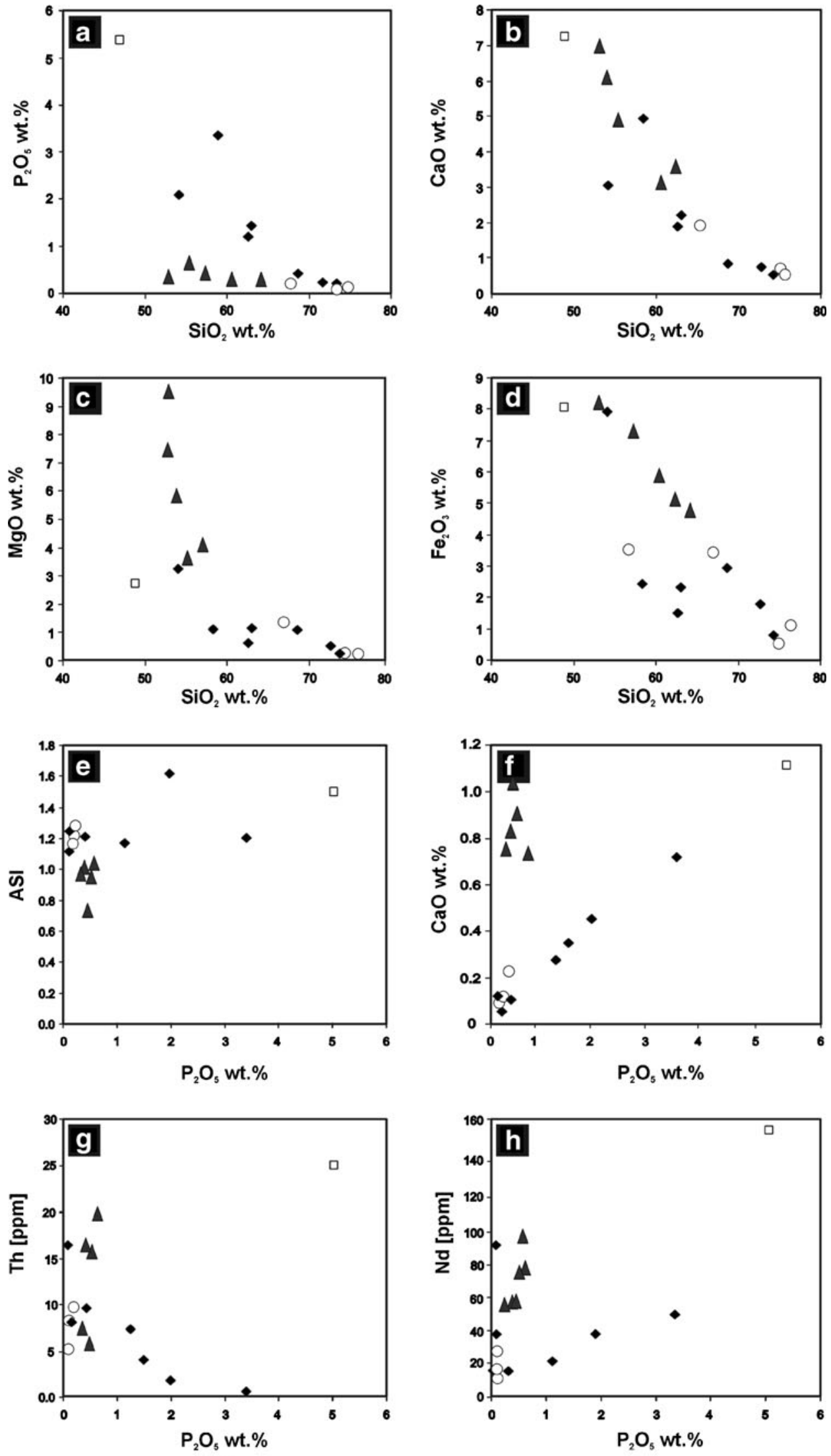

Quartz-diorites

Apatite-rich cumulative enclave

O Granitoids

Apatite-bearing cumulates 
Fig. 6 Variation diagrams for the apatite-bearing granitoids, quartz diorites and homogeneous granitoids of the Western Tatra Mts. Apatite-rich enclave from the High Tatra Mts (Gawęda 2008) plotted for reference. Calculated liquids (MIX and L) as well as cumulate $(\mathrm{CUM})$ are marked in figures $\mathbf{a}-\mathbf{f}$

observed in samples rich in alkali feldspars. Sr contents in the range of 506-153 ppm (Table 4) show no significant correlation with $\mathrm{P}_{2} \mathrm{O}_{5}$. The highest fluorine contents are observed in samples high in $\mathrm{P}_{2} \mathrm{O}_{5}$. Whole-rock $\mathrm{Zr}$ contents range between 157 and 8.2 ppm (Table 4) and most of the zircon crystals are either inherited or contain inherited cores (Burda and Gawęda, personal informations).

Total REE contents in whole-rock samples are relatively low (95-250 ppm). Chondrite (C1)-normalized REE patterns are characterised by low REE fractionation, expressed by $\mathrm{Ce}_{\mathrm{N}} / \mathrm{Yb}_{\mathrm{N}}$ in the range of 2.35-9.74 and negative $\mathrm{Eu}$ anomalies $\left(\mathrm{Eu} / \mathrm{Eu}^{*}=0.43-0.71\right.$; Fig. 8; Table 4).

Associated granites show ASI values in the range of 1.148-1.285 (samples SR10, SW2100B), negative Eu anomalies (0.7-0.8) and moderate to high REE fractionation indices (Table 5).

\section{Apatite chemistry and cathodoluminescence}

All of the apatites are fluor-apatites with $<3.99 \mathrm{wt} . \% \mathrm{~F}$ and $<0.08$ wt. $\% \mathrm{Cl}$. Si and S contents rarely exceed 0.13 and 0.06 wt.\%, respectively (Table 6). $\mathrm{MnO}$ ranges from of 0.18 to 0.51 wt. $\%$ with an average of 0.34 wt. $\%$ (Table 6). The relatively high $\mathrm{MnO}$ content is responsible for the intense yellow $\mathrm{CL}$ colour observed in both apatite types as $\mathrm{Mn}^{+2}$ is the main CL activator causing CL emission at $560-575 \mathrm{~nm}$ in apatite (Fig. 5a, b, c, d and f; Gaft et al. 1997; Blanc et al. 2000). Micro-zoning of monovalent cations is observed in the $A p_{1}$

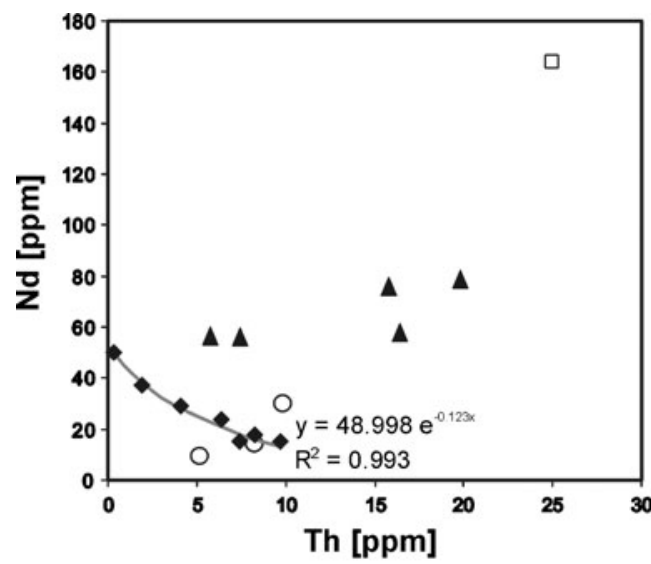

Apatite-bearing cumulates $\square$ Apatite-rich cumulative enclave

Granitoids $\Delta$ Quartz-diorites

Fig. 7 Trace-element variation diagrams for the apatite-bearing granitoids, quartz diorites and homogeneous granitoids of the Western Tatra Mts. For the apatite-rich rocks the trend is described by the equation and $\mathrm{R}^{2}$ value

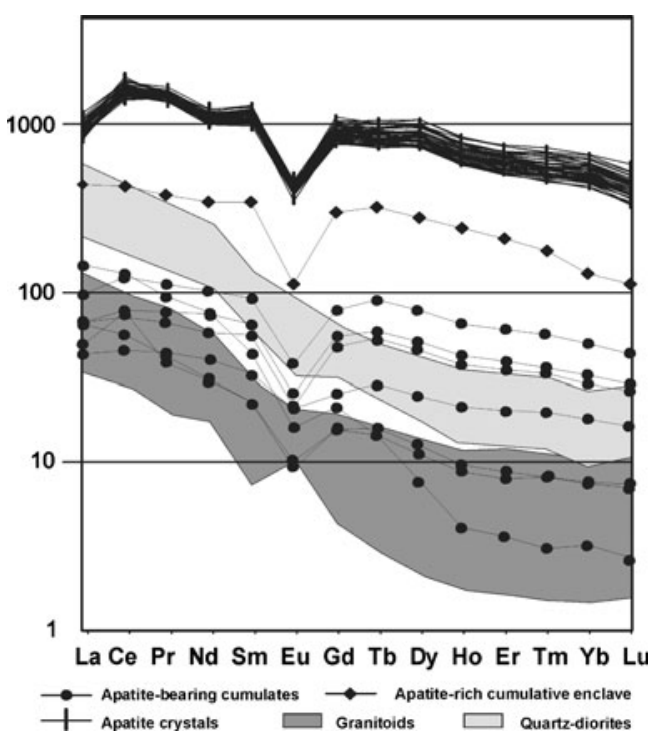

Fig. 8 Chondrite (C1)-normalized REE diagram for the apatitebearing rocks and apatite. Apatite-rich enclave from the High Tatra granite is used for reference. Light grey area REE patterns of quartz diorites, dark-grey area REE patterns of homogeneous granitoids

type (Table 6; Fig. 9a, b and c). That type is characterised by the presence of dark luminescing cores, enriched in REE and $\mathrm{Y}$ (Fig. 10), overgrown by brightly luminescing rims (Fig. 5a). In the cores $\mathrm{FeO}$ and $\mathrm{MgO}$ contents reach up to 0.68 wt.\% (average 0.21 wt.\%) what, together with $\mathrm{Y}$ and REE enrichment, could cause CL suppression (Fig. 9b; Table 6, analyses 1-15). Xenomorphic $\mathrm{Ap}_{2}$ crystals show no zoning and uniform $\mathrm{CL}$ colours similar to those of the margins of $\mathrm{Ap}_{1}$ crystals (Fig. 5c, $\mathrm{d}$ and f). Locally a patchy colour distribution could be observed, caused by $\mathrm{Y}$ and $\mathrm{Fe}$ enrichment.

Strontium contents, analysed by LA-ICPMS, are relatively low in the range of $288-498 \mathrm{ppm}$ with a mean of $369 \mathrm{ppm}$ (Table 7). The average concentration of yttrium is $1044 \mathrm{ppm}$ (Table 7).

Total rare earth element (REE) contents range from 2438 to 2998 ppm (Table 7). Chondrite (C1)-normalized REE patterns show negative $\mathrm{Eu}$ anomalies (mean $\mathrm{Eu} / \mathrm{Eu}^{*}=\sim 0.41$ ) for all crystals (Table 7; Fig. 8). A most prominent feature is the LREE enrichment $\left(\mathrm{Ce}_{\mathrm{N}} / \mathrm{Yb}_{\mathrm{N}}=2.34-4.11\right.$; Table 6$)$, due mainly to the enhanced $\mathrm{Ce}$ contents and the positive $\mathrm{Ce}$ anomalies (mean $\mathrm{Ce} / \mathrm{Ce}^{*}=\mathrm{Ce} / \sqrt{ }(\mathrm{La} \cdot \mathrm{Pr}) \sim 1.37$; Table 7 ). In all of the $\mathrm{CL}$ spectra, peaks at 361 (363) and $374 \mathrm{~nm}$ are linked to the presence of Ce (Gaft et al. 1997).

\section{Discussion}

The mechanisms of apatite accumulations

In granitoid magmas, concentrations of apatite crystals can result from 1) gravity-driven separation in magma of low 
Table 5 Chemical compositions of selected rock samples which were used for the mixing modelling

\begin{tabular}{|c|c|c|c|c|}
\hline Sam no. & $\begin{array}{l}\text { SR10 } \\
\text { gr }\end{array}$ & $\begin{array}{l}\text { SW } 2100 \mathrm{~B} \\
\mathrm{gr}\end{array}$ & $\begin{array}{l}\text { NB } \\
\text { gr }\end{array}$ & $\begin{array}{l}\text { D31a } \\
\text { dior }\end{array}$ \\
\hline $\mathrm{SiO}_{2}$ & 66.89 & 69.58 & 72.42 & 52.75 \\
\hline $\mathrm{TiO}_{2}$ & 0.6 & 0.38 & 0.22 & 1.29 \\
\hline $\mathrm{Al}_{2} \mathrm{O}_{3}$ & 16.78 & 14.8 & 14.68 & 16.1 \\
\hline $\mathrm{Fe}_{2} \mathrm{O}_{3 \mathrm{~T}}$ & 3.58 & 2.57 & 1.86 & 8.36 \\
\hline $\mathrm{MnO}$ & 0.05 & 0.05 & 0.04 & 0.14 \\
\hline $\mathrm{MgO}$ & 1.38 & 1.31 & 0.53 & 7.47 \\
\hline $\mathrm{CaO}$ & 1.98 & 1.77 & 0.75 & 5.19 \\
\hline $\mathrm{Na}_{2} \mathrm{O}$ & 4.12 & 4.02 & 4.08 & 3.58 \\
\hline $\mathrm{K}_{2} \mathrm{O}$ & 2.92 & 3.29 & 4.01 & 2.01 \\
\hline $\mathrm{P}_{2} \mathrm{O}_{5}$ & 0.2 & 0.21 & 0.08 & 0.33 \\
\hline LOI & 1.90 & 1.03 & 1.00 & 3.01 \\
\hline Total & 100.49 & 99.01 & 99.70 & 100.23 \\
\hline $\mathrm{Sr}$ & 456.9 & 596.3 & 458.4 & 647.0 \\
\hline $\mathrm{Ba}$ & 759 & 1528 & 1418 & 734 \\
\hline $\mathrm{Rb}$ & 98.7 & 86.8 & 72.6 & 58 \\
\hline Th & 9.8 & 16.5 & 7.5 & 7.44 \\
\hline $\mathrm{U}$ & 1.5 & 2.5 & 1.0 & 3.45 \\
\hline $\mathrm{Ga}$ & 20.2 & 20.6 & 15.3 & 18.0 \\
\hline $\mathrm{Zr}$ & 140.6 & 169.6 & 107.1 & 80 \\
\hline $\mathrm{Hf}$ & 4 & 5.3 & 3.4 & 2.6 \\
\hline $\mathrm{Y}$ & 11.6 & 10.4 & 18.1 & 28.5 \\
\hline $\mathrm{Nb}$ & 7 & 6.6 & 3.8 & 7.4 \\
\hline $\mathrm{Ta}$ & 0.4 & 0.3 & 0.3 & 0.4 \\
\hline $\mathrm{La}$ & 28.8 & 46.4 & 25 & 53.4 \\
\hline $\mathrm{Ce}$ & 61.6 & 100.5 & 52.1 & 108 \\
\hline $\operatorname{Pr}$ & 7.5 & 11.28 & 6.04 & 13.3 \\
\hline $\mathrm{Nd}$ & 27.1 & 42.3 & 23.6 & 55.5 \\
\hline $\mathrm{Sm}$ & 4.43 & 7.1 & 4.21 & 10.1 \\
\hline $\mathrm{Eu}$ & 0.97 & 1.24 & 1.06 & 3.1 \\
\hline $\mathrm{Gd}$ & 3.13 & 4.18 & 3.46 & 7.84 \\
\hline $\mathrm{Tb}$ & 0.43 & 0.51 & 0.55 & 1.07 \\
\hline Dy & 2.39 & 2.27 & 3.03 & 5.57 \\
\hline Ho & 0.41 & 0.32 & 0.61 & 1.01 \\
\hline $\mathrm{Er}$ & 1.09 & 0.81 & 1.7 & 2.75 \\
\hline $\mathrm{Tm}$ & 0.16 & 0.12 & 0.24 & 0.357 \\
\hline $\mathrm{Yb}$ & 0.89 & 0.78 & 1.44 & 2.34 \\
\hline $\mathrm{Lu}$ & 0.13 & 0.11 & 0.2 & 0.326 \\
\hline $\mathrm{F}$ & 470 & 320 & 70 & nd \\
\hline ASI & 1.285 & 1.148 & 1.201 & 0.963 \\
\hline $\mathrm{Rb} / \mathrm{Sr}$ & 0.216 & 0.146 & 0.158 & 0.089 \\
\hline $\mathrm{Nd} / \mathrm{Th}$ & 2.765 & 2.564 & 3.147 & 7.446 \\
\hline$\Sigma \mathrm{REE}$ & 139.03 & 217.92 & 123.24 & 264.663 \\
\hline $\mathrm{Eu} / \mathrm{Eu}^{*}$ & 0.796 & 0.696 & 0.849 & 1.065 \\
\hline $\mathrm{Ce}_{\mathrm{N}} / \mathrm{Yb}_{\mathrm{N}}$ & 19.070 & 35.501 & 9.969 & 12.717 \\
\hline
\end{tabular}

gr granitoid, dior diorite, ASI (aluminium saturation index) $=$ mol. $\mathrm{Al}_{2} \mathrm{O}_{3} /\left(\mathrm{K}_{2} \mathrm{O}+\mathrm{Na}_{2} \mathrm{O}+\mathrm{CaO}-3.33 \mathrm{P}_{2} \mathrm{O}_{5}\right) ; \mathrm{Eu} / \mathrm{Eu}^{*}=\mathrm{Eu}_{\mathrm{N}} /\left(\sqrt{ } \mathrm{Sm}_{\mathrm{N}} \cdot \mathrm{Gd}_{\mathrm{N}}\right)$ viscosity (Bacon 1989) aided, perhaps, by flowage differentiation (Broska et al. 2008; Gawęda and Szopa 2011), 2) local saturation in a chemical boundary layer around feldspars (Watson and Capobianco 1981; Harrison and Watson 1984; Bacon 1989) or 3) synneusis of minerals along low free energy crystallographic planes (Bacon 1989).

In the presented case, textural observations of two types of apatite suggest two different ways of their accumulation. In case of the first type of the long-prismatic and strongly zoned apatite $\left(\mathrm{Ap}_{1}\right)$ crystals the preferred mechanism is their segregation together with biotite $\left(\mathrm{Bt}_{1}\right)$, locally squeezed into the crystal interstices between growing feldspars (Figs. $3 \mathrm{~b}$ and d) or attached to their faces (Fig. 5b). That mechanism, describing the origin of the cumulative fabric of the apatiterich rocks and local concentrations of $\mathrm{Ap}_{1}+\mathrm{Bt}_{1}$ is in agreement with the proposed origin of magmatic layering, found in the Tatra granite (Gawęda and Szopa 2011). Cumulates and sedimentary-like structures from the Tatra granite intrusion were suggested to be formed as a result of complex interaction of gravity-driven accumulation, flow sorting and deposition on the magma floor and on the surfaces of large xenoliths, filter pressing and density currents initiated by tectonic activity (Gaweeda and Szopa 2011). Moreover, the presence of the $\mathrm{Ap}_{1}$ cores, showing higher contents of $\mathrm{Mg}$, Fe, Y and REEs (Fig. 9a, b c, Table 6), identical to those found in the quartz-diorites (Gawęda et al. 2005) and associated granitoids, characterised by mixing-mingling features, and therefore interpreted as hybrids (Burda et al. 2011), as well as $\mathrm{Bt}_{1}$, chemically resembling biotite from quartz-diorites, could be interpreted as possible remnants from the diorite intrusion.

Xenomorphic apatite $\left(\mathrm{Ap}_{2}\right)$ is intergrown with feldspars and could represent the second or third mechanisms: local saturation of phosphorus in a chemical boundary layer caused the concentration of apatite crystals near K-feldspar crystal faces and inside plagioclases or synneusis (Figs. 3d, $4 c, 5 c$ and f). However, the melt from which they crystallized ought to be rich in phosphorus.

The crystallization of apatite depends on the chemistry of the parent magma. Melt aluminosity is a key factor in creating the conditions for major- and accessory-mineral assemblages' crystallization. The apatite-rich rocks are peraluminous in composition (Table 4; Fig. 6e). High ASI values, typical of peraluminous rocks, enhance apatite solubility and thus favour higher phosphorus content in granitoid melts (Wolf and London 1994; Bea 1996; Sha and Chappell 1999). In the investigated rocks, high ASI (Fig. 6e; Table 4) forced the alkali feldspar crystallization. Alkali feldspars monitor the P content of a granitic melt "if they are essentially Ca-free, in equilibrium with the bulk melt and if the other components do not substantially modify $\mathrm{AlPO}_{4}$ in melt" (London et al. 1999). In the Tatra rocks described here, most of the $\mathrm{Ca}$ and $\mathrm{F}$ budget was controlled 


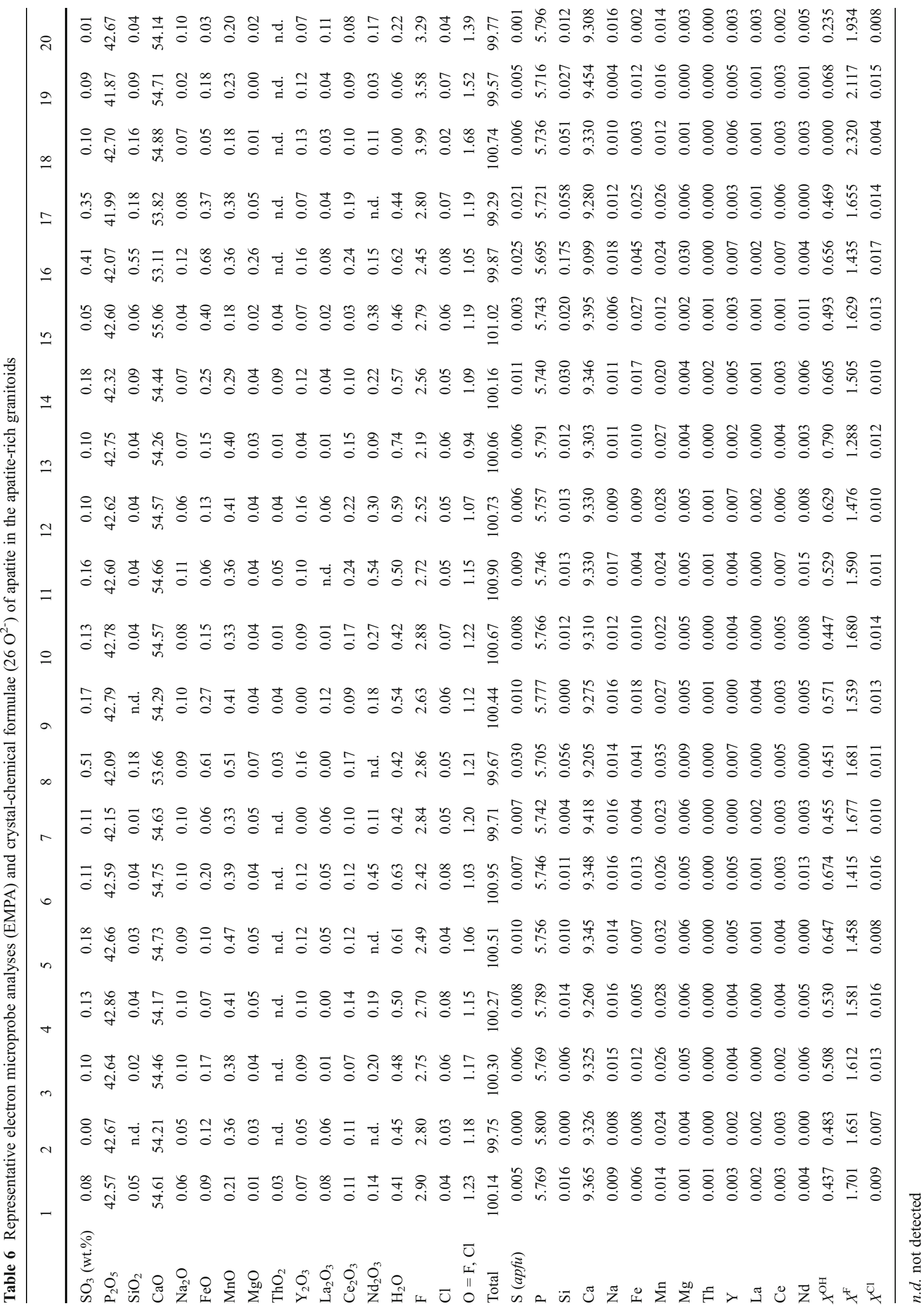


Fig. 9 Cathodoluminescence image of apatite $\left(\mathrm{Ap}_{1}\right)$ with clearly-visible zoning (a). The zoning is due to changes in apatite composition involving main- and some trace elements (b). In addition, different ratios of substituted $\mathrm{OH}^{-}$and $\mathrm{F}^{-}$ions are detected $(\mathbf{c})$

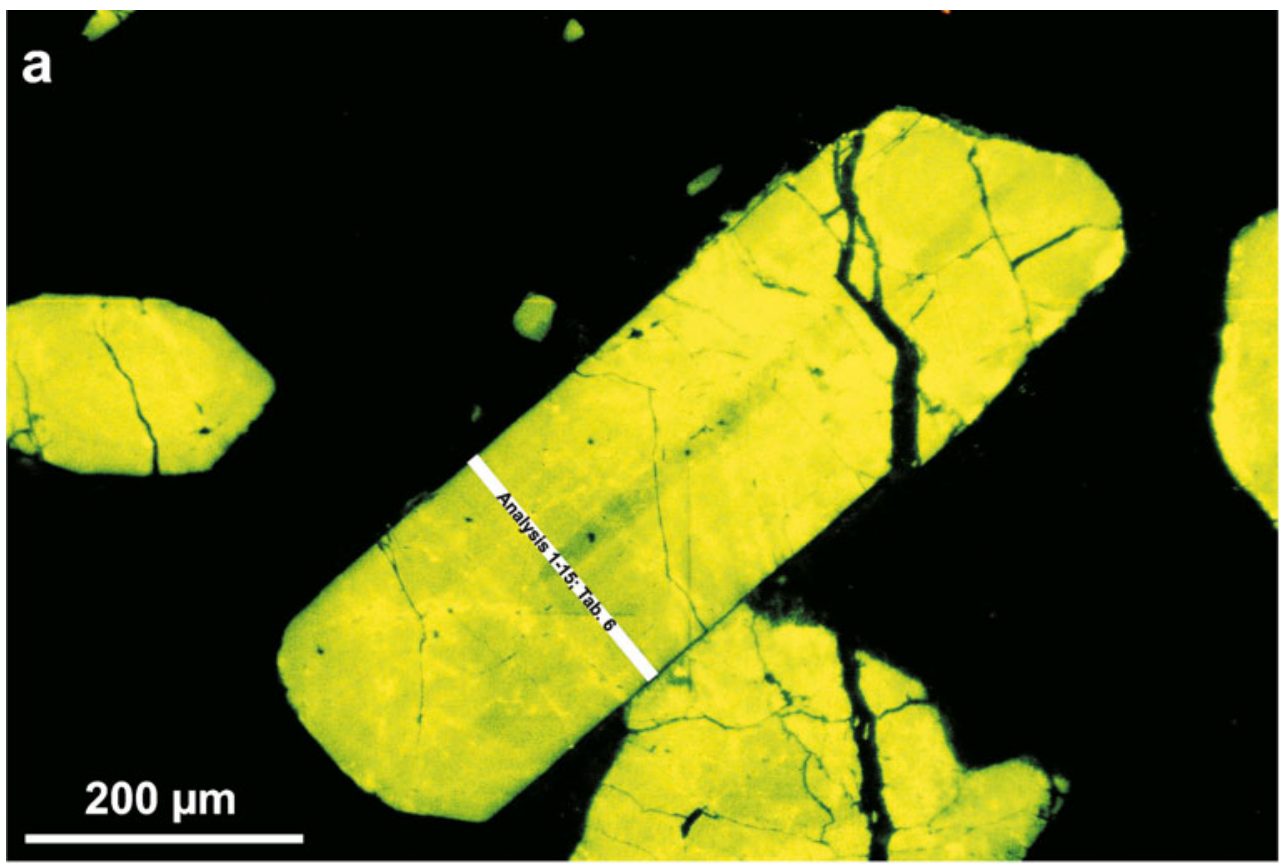

b

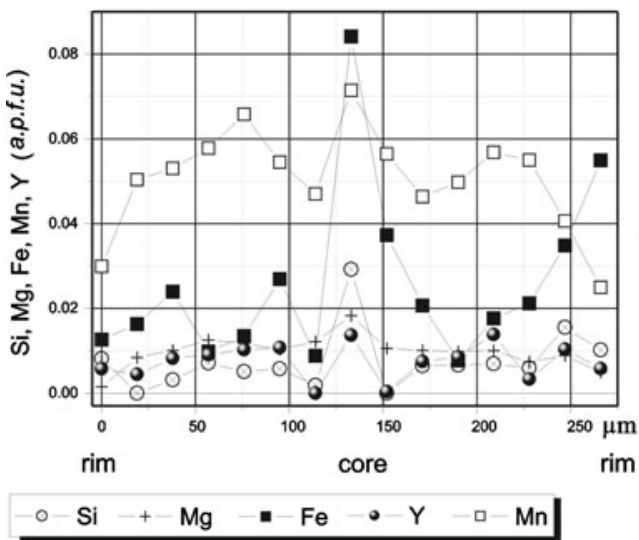

C

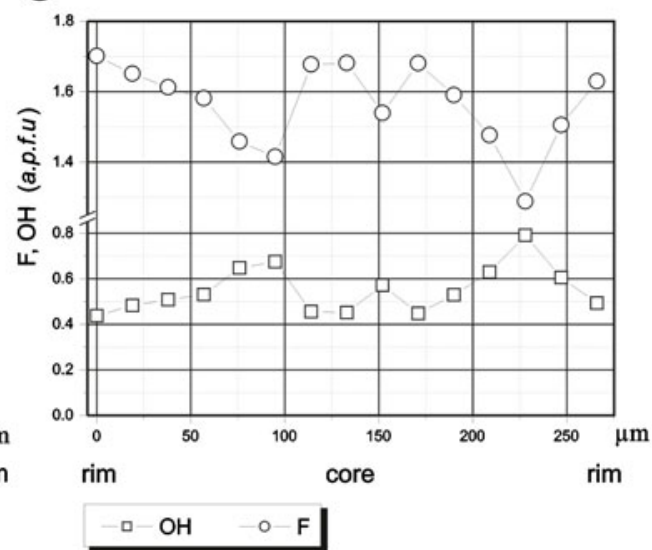

by apatite crystallization (Wolf and London 1994). The experimental reaction (London et al. 1999):

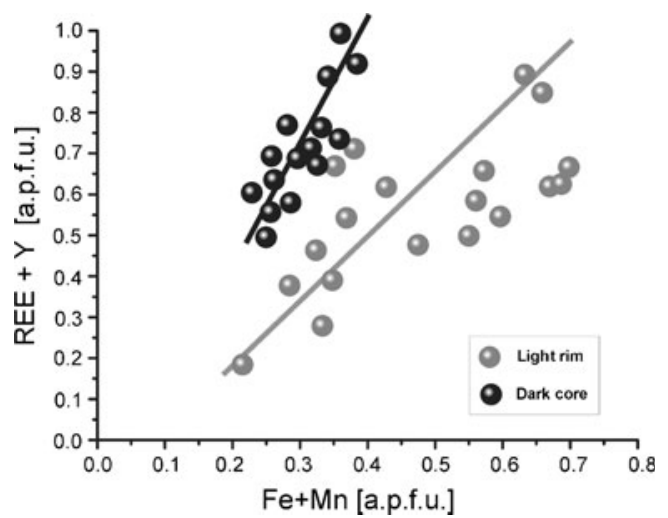

Fig. 10 Chemical diversification of cores and rims of zoned apatite crystals in terms of $(\mathrm{REE}+\mathrm{Y})$ versus $(\mathrm{Fe}+\mathrm{Mn})$ cations
$10 \mathrm{CaAl}_{2} \mathrm{Si}_{2} \mathrm{O}_{8}+3 \mathrm{P}_{2} \mathrm{O}_{5}+\mathrm{F}_{2} \mathrm{O}_{-1}$

$$
=2 \mathrm{Ca}_{5}\left(\mathrm{PO}_{4}\right)_{3} \mathrm{~F}+10 \mathrm{Al}_{2} \mathrm{SiO}_{5}+10 \mathrm{SiO}_{2}
$$

can be applied to the apatite-rich rocks of the Western Tatra Mts, assuming that the $\mathrm{Al}_{2} \mathrm{SiO}_{5}$ is consumed in further alkali feldspar-forming reactions. The presence of K-feldspar coatings on the relatively large apatite crystals included in albiteoligoclase (e.g. Fig. 3a) and the xenomorphic shape of apatite included in K-feldspars which might be interpreted as a result of interaction with feldspar crystal planes, and fits with the model based on the local saturation of $(\mathrm{P}, \mathrm{Ca}, \mathrm{F})$ versus $(\mathrm{K}, \mathrm{Na}, \mathrm{Al}, \mathrm{Si}, \mathrm{Ba})$ in the feldspar border zones.

The assumption that local saturation is the main factor influencing apatite crystallisation suggests very slow elemental diffusion in the parent magma. Possibly it was not a pure melt but rather a crystal-laden melt with feldspars and apatite crystallizing simultaneously as cumulus minerals. Such a hypothesis seems plausible especially for the 


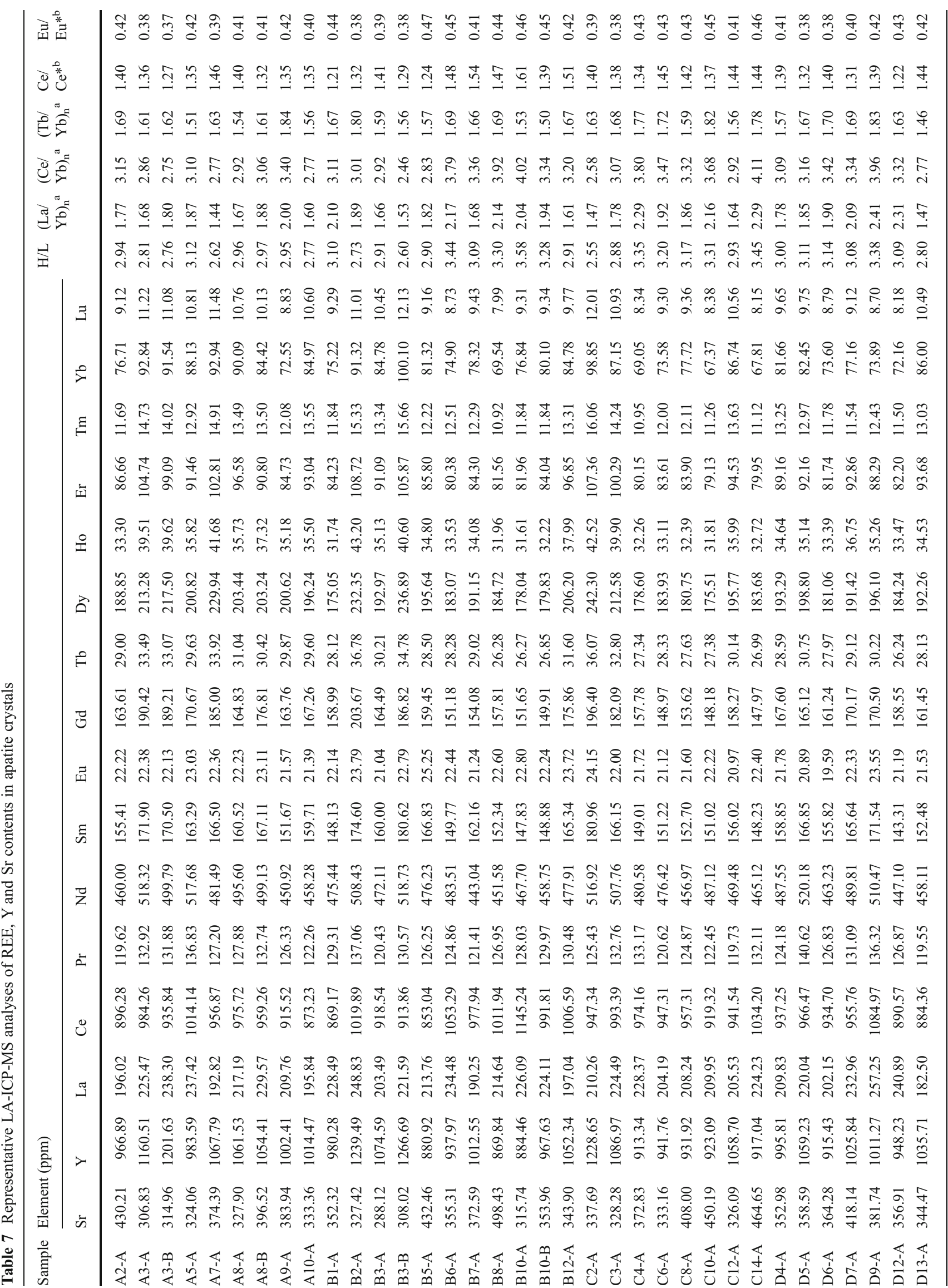




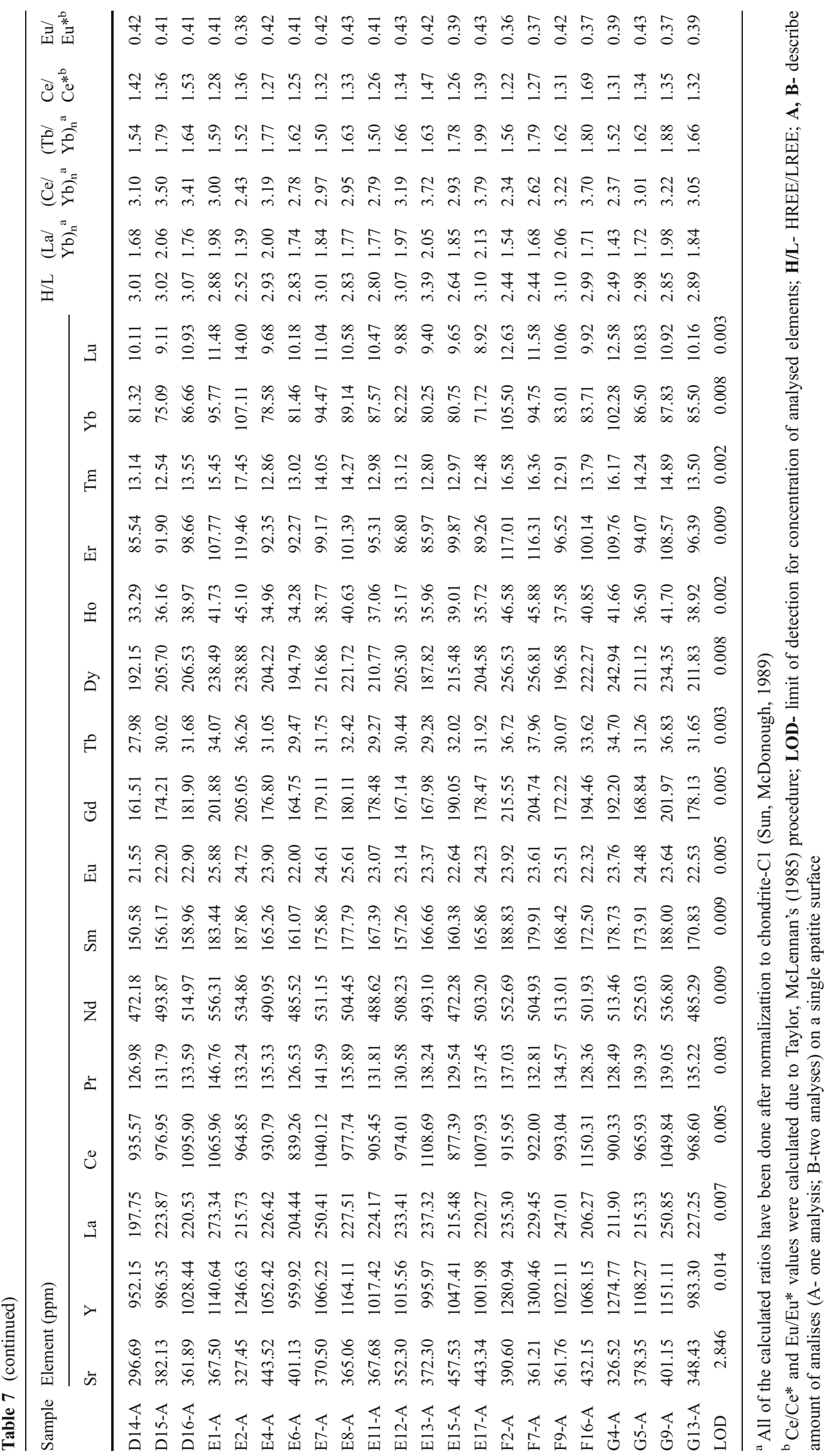


irregular $\mathrm{Ap}_{2}$ apatite crystals. These irregular $\mathrm{Ap}_{2}$ crystals (Fig. 3f) most probably crystallized in a system possibly characterised by high diffusivity and chemically-stable conditions, resulting in the lack of any or very weak zoning (Dempster et al. 2003). The homogeneous compositions of $\mathrm{Ap}_{1}$ crystal margins, and of the whole $\mathrm{Ap}_{2}$ crystals is indicative of chemical stability during the late crystallization stage.

The origin of the apatite-rich granitoid rocks

In the Central Western Carpathians, as in most of the granite provinces in the world, apatite enrichment is a typical feature of I-type granites (Broska et al. 2004; Sha and Chappell 1999). Consequently, the abundance of apatite might suggest an I-type affinity for the parent magma of the investigated apatite-rich granitoid rocks.

The field occurrence of the apatite-rich rocks indicates a physical link with the underlying quartz-diorites and hybrid rocks or with the homogeneous granitoids (Fig. 2). The geochemical characteristics of the three rock types (apatite-rich rocks, quartz-diorites and homogeneous granites) diverge. However, variation diagrams and the weak LREE enrichment on chondrite-normalized REE diagrams (Figs. 6a, 7, 8 and 9) suggest their genetic link. The presence of zoned $\mathrm{Ap}_{1}$ apatite crystals together with $\mathrm{Bt}_{1}$, similar to apatite and biotite from hybrid quartz-diorites (Gawęda et al. 2005; Burda et al. 2011) also supports the genetic link between the apatite-rich rocks and mafic precursors of the Tatra granite intrusion.

The high ASI values in $\mathrm{P}_{2} \mathrm{O}_{5}$-rich rocks (Fig. 6e) suggests an S-type affinity (Broska et al. 2004). In addition, the negative Eu anomaly in the whole-rock chondritenormalized REE diagrams is indicative of an S-type, reduced, parental granitoid magma. Reduced conditions are also supported by the apatite chemistry; high apatite $\mathrm{Mn}$ (as $\mathrm{Mn}^{+2}$ ) contents and the pronounced negative Eu anomalies reflect high $\mathrm{Eu}^{+2} / \mathrm{Eu}^{+3}$ preventing Eu enrichment in the apatite structure, but enabling $\mathrm{Mn}^{+2} \leftrightarrow \mathrm{Ca}^{+2}$ substitution (Sha and Chappell 1999).

The apatite enrichment in $\mathrm{Y}$ might mislead interpretations of the geotectonic setting of the rocks (Fig. 11). The granitoids of the Tatra Mountains plot in the VAG and synCOLG fields (Gawęda et al. 2005; Gawęda 2009). The observed shift into the ORG field is caused by the concentration of apatite, the main carrier of $\mathrm{Y}$ in the analysed rocks. This fact suggests that careful textural and mineralogical studies should be done before any geotectonic interpretations based on the trace elements.

All these data suggest that apatite-rich rocks contain both S-type and I-type characteristics and their formation was influenced by magmas from both sources.

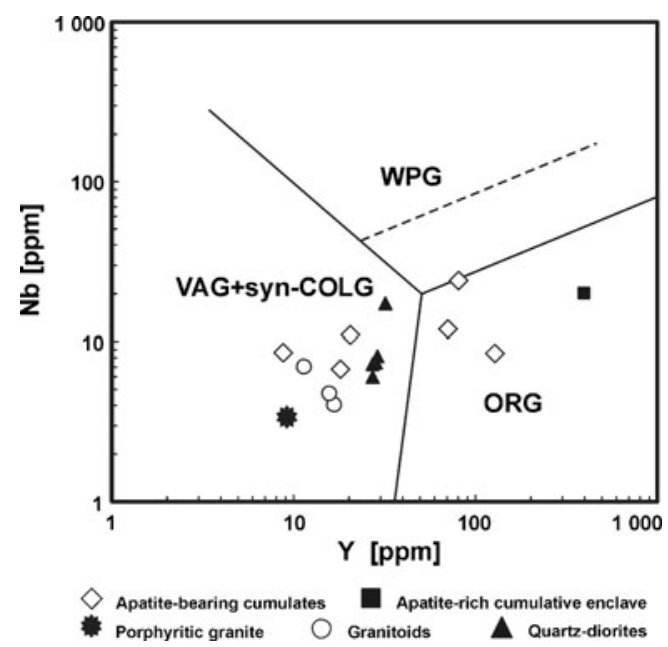

Fig. 11 The analysed granitoid rocks plotted on the geotectonic diagram of Pearce et al. (1984). VAG volcanic arc granites, syn-COLG syn-collisional granites, $O R G$ ocean ridge granites, $W P G$ within-plate granites

The cumulate development

The cumulate definition, used in this study, follows the meaning given by Irvine (1982). Consequently, the magmatic cumulate is a rock, dominated by "a cumulus framework of touching crystals, formed and concentrated primarily through fractional crystallization" (Irvine 1982). In the described case the parental magma composition is supposed on the basis of field relationships. The definition given by Irvine (1982) does not preclude the process, leading to a separation of cumulus minerals. In case of relatively viscous granitoid melts the mineral separation and cumulate formation is a result of complex interactions of sorting and filter pressing during flow and strain acting in crystal mushes and gravity-controlled crystal settling (Vernon and Paterson 2008).

The curved and broken trends in some variation diagrams preclude any simple two-component mixing/mingling of mafic and felsic magmas (Figs. 6a-d and 7) as was identified in the quartz-diorite suite (Gawęda et al. 2005) and hybrid granitoid rocks from the same area (Burda et al. 2011), as well as precluding any simple fractionation trend. Anyway, the observed chemical zonation of feldspars (e.g. Ba zoning in alkali feldspars (Table 3; Burda et al. 2011; Gawęda and Sikorska 2010) and apatite reflects the variations in magma chemistry during crystallization. There is no evidence for important diffusive modification of the apatite and alkali feldspars composition during later crystallization. Late albitization only locally caused the disappearance of primary CL-signal of plagioclase crystals (Fig. 5b and d).

The basic assumption for the geochemical modelling was the mixing of quartz-diorite magma with partial leucocratic melt, squeezed from metasediments. These leucogranites, 
called traditionally alaskites (Jaroszewski 1965; Gawęda 2001), are considered as final products of large scale partial melting and migmatization of metapelites at $365-360 \mathrm{Ma}$ (Burda and Gawęda 2009). High activity of phosphorus, noted in these magmas, is shown by coexistence of apatite with zircons showing $\mathrm{P}$ and $\mathrm{Y}$ enrichment (Burda and Gawęda 2009). These leucocratic magmas were suggested earlier as the main contaminants for quartz-diorites from the Western Tatra Mountains (Gawęda et al. 2005). A resulting mixture was of granitic composition (Mix; Table 8). Possibly the deviations from the mixing line (Fig. 6a, b, c and d) could be caused by a multi-step cumulate formation processes and squeezing out the remnant melt.

For the supposed mixing process the geochemical mass balance law: $\mathrm{C}_{\mathrm{M}}=\mathrm{X}_{\mathrm{A}} \cdot \mathrm{C}_{\mathrm{A}}+\left(1-\mathrm{X}_{\mathrm{A}}\right) \cdot \mathrm{C}_{\mathrm{B}}$ (Rollinson 1993) was used for major and trace elements to test the mixing hypothesis. For the purpose of this study A represents a felsic component and $\mathrm{B}-\mathrm{a}$ mafic component. $\mathrm{C}_{\mathrm{A}}$, $\mathrm{C}_{\mathrm{B}}, \mathrm{C}_{\mathrm{M}}$ are concentrations of a given element in felsic, mafic and mixed melts (Tables 5, 8 and 9). For the derived equation $\mathrm{y}=\mathrm{X}_{\mathrm{A}} \mathrm{x}$ (where $\mathrm{y}=\mathrm{C}_{\mathrm{M}}-\mathrm{C}_{\mathrm{B}}$ and $\mathrm{x}=\mathrm{C}_{\mathrm{A}}-\mathrm{C}_{\mathrm{B}}$ ) for the mixing line $0.889 \mathrm{x}+1.37$ shows $R^{2}=0.943$ (Fig. 12).

The formation and removal of a cumulate is one of the mechanisms causing magma fractionation (Cox et al. 1984). To test this assumption the geochemical modelling was applied (Table 9, Fig. 12).

Next step of geochemical modelling was formation of a cumulate, composed of $8 \% \mathrm{Ap}_{2}+12 \% \mathrm{Bt}_{2}+66 \% \mathrm{Pl}+9 \% \mathrm{Kfs}$ $+5 \%$ Qtz. The resulting cumulate is similar in composition to natural cumulate sample SR9 (MSWD=0.638; Table 9). Detailed field mapping suggested that apatite-rich cumulates form about $8 \%$ of the exposed profile, so that amount of cumulate was removed from the sample Mix. The resulting felsic melt was compared to the sample SW2100. The resulting value of $\sqrt{\mathrm{MSWD}}=3.31$ is acceptable, taking into account possible local hydrothermal alterations of rocks and some elements ( $\mathrm{Si}, \mathrm{Fe}, \mathrm{K}, \mathrm{Mg}$ ) mobility (Gaweda and Włodyka 2013; Table 9 - most of the $\mathrm{R}^{2}$ difference is caused by silica).

The weakness of this model is the assumption of biotite as a cumulate phase. Here we have to consider the transformation of the primary mafic minerals (e.g. formation of so called mafic cloths composed of biotite, amphibole and magnetite after primary pyroxene, Gawęda et al. 2005), which is a common process during mixing-mingling phenomena (e.g. Hibbard 1991; Baxter and Feely 2002). The progressive replacement of anhydrous mafic phases and amphiboles by biotite and at least partial re-equilibration of their chemistry inside the host granite should be also considered as one of the important processes taking place before the granite ascent (Lavaure and Sawyer 2011). All these facts allow the interpretation that the currently observed biotite can be treated as a chemical representation of former mafic phases.

The simulation presented above should be treated as a simplification. Cumulate fraction could be separated at all stages of mixing, so possibly the compositional changes of cumulative samples results from the complex processes interacting: degree of mixing, percent of cumulate removed, etc.

As gravity-driven accumulation alone seems to be improbable, especially when assuming biotite as cumulate phase (Table 9), flow differentiation coupled with filter pressing could be the most appropriate mechanism for cumulate segregation, as in other cases from the Western Carpathians (Broska et al. 2008).

Chondrite (C1)-normalized REE whole-rocks patterns of apatite-rich rocks mimic those of the apatites. Low REE fractionation in the apatite-rich rocks, as expressed by $\mathrm{Ce}_{\mathrm{N}} / \mathrm{Yb}_{\mathrm{N}}$ in the range 2.35-9.74, is, however, higher than that of pure apatite (compare Tables 3,6 and Fig. 8). Comparison of the REE patterns and $\mathrm{Ce}_{\mathrm{N}} / \mathrm{Yb}_{\mathrm{N}}$ ratios of
Table 8 Results of the geochemical modelling mixing processes (MIX)

All analyses are recalculated to $100 \%$

\begin{tabular}{lcccccc}
\hline Component & Diorite D31a & Leucogranite NB & $\begin{array}{l}\text { Computed mix } \\
(30 \% \text { mafic }+70 \% \text { felsic })\end{array}$ & $\begin{array}{l}\text { Granite } \\
\text { SR10 }\end{array}$ & MIX-SR10 (R) & $R^{2}$ \\
\hline $\mathrm{SiO}_{2}$ & 54.2 & 73.37 & 67.62 & 67.87 & 0.25 & 0.0625 \\
$\mathrm{TiO}_{2}$ & 1.33 & 0.22 & 0.55 & 0.61 & 0.06 & 0.0036 \\
$\mathrm{Al}_{2} \mathrm{O}_{3}$ & 16.54 & 14.87 & 15.37 & 17.01 & 1.64 & 2.6896 \\
$\mathrm{Fe}_{2} \mathrm{O}_{3}{ }^{*}$ & 8.59 & 1.88 & 3.89 & 3.65 & -0.24 & 0.0576 \\
$\mathrm{MnO}$ & 0.14 & 0.04 & 0.07 & 0.05 & -0.02 & 0.0004 \\
$\mathrm{MgO}$ & 7.68 & 0.54 & 2.68 & 1.4 & -1.28 & 1.6384 \\
$\mathrm{CaO}$ & 5.33 & 0.76 & 2.13 & 2.01 & -0.12 & 0.0144 \\
$\mathrm{Na}_{2} \mathrm{O}$ & 3.68 & 4.14 & 4.00 & 4.17 & 0.17 & 0.0289 \\
$\mathrm{~K}_{2} \mathrm{O}$ & 2.07 & 4.07 & 3.47 & 2.98 & -0.49 & 0.2401 \\
$\mathrm{P}_{2} \mathrm{O}_{5}$ & 0.34 & 0.08 & 0.16 & 0.2 & 0.04 & 0.0016 \\
$\mathrm{~F}$ & 0.1 & 0.03 & 0.05 & 0.05 & 0.00 & 0.0000 \\
$\mathrm{Total}$ & 100 & 100 & 100 & 100 & 0.01 & 4.7371 \\
\hline
\end{tabular}


the whole rocks and apatite crystals reveals similar, rather small REE fractionation, interpreted here to indicate that apatite is the mineral that controls the REE concentration and fractionation in the parent magma.

The positive correlation of $\mathrm{Nd}$ versus $\mathrm{P}_{2} \mathrm{O}_{5}$ in the apatiterich rocks $\left(r^{2}=0.95\right.$; Fig. $\left.6 \mathrm{~h}\right)$, together with negative correlation of Th versus $\mathrm{P}_{2} \mathrm{O}_{5}\left(R^{2}=0.86\right.$; Fig. $\left.6 \mathrm{~g}\right)$ suggest that apatite was the carrier of $\mathrm{Nd}$ but not a sink for $\mathrm{Th}$, causing the opposite behaviour of both trace elements (Bea et al. 1999). This is also typical of the magmatic rocks in the Western Tatra Mountains (Gawęda et al. 2005; Burda et al. 2011). Samples with the highest phosphorus contents form a separate negative trend on the Nd versus Th diagram $\left(R^{2}=0.993\right.$; Fig. 7), suggesting either a mantle influence in the parent magma (e.g. Bea et al. 1999) or the physical concentration of Nd-bearing phases. As the apatite is the dominant carrier of REE in the described rocks (Table 6), the latter explanation seems plausible.

The cumulative sample (G2 - Gawęda 2008; Table 4) used as a reference sample shows more or less the same trends as the apatite-rich rocks (Figs. 6e-h). Observed differences can be explained by the different degree of segregation, domination of $\mathrm{K}$-feldspars over plagioclases and presence of xenotime, monazite and opaque minerals (Gaweda 2008) which are either scarce or lacking in the cumulates described here. Moreover, the cumulate sample from the High Tatra Mountains underwent a thermal overprint by the younger host granite ( $345 \mathrm{Ma}$, recorded by zircon rims; Gawęda 2008). However, both G2 cumulate enclave and cumulate horizons from the Western Tatra Mountains might represent the same process of segregation and comparable ages: $361 \pm 7$ for the G2 enclaves (Gawęda 2008) and $368 \pm 8$ for the hybridization process (Burda et al. 2011).

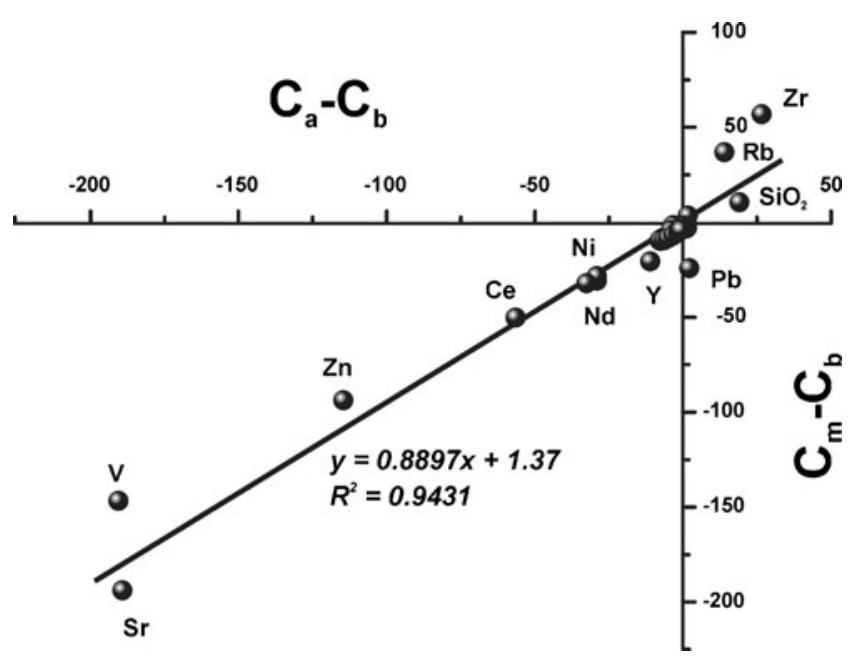

Fig. 12 Graphical presentation of the mixing test (according to Rollinson 1993). Numerical data could be found in the Table 5 


\section{Conclusions}

The findings of this study can be summarized as follows:

1. Apatite-rich granitoid rocks, located in a transitional zone between I-type quartz diorites (mafic precursors) and felsic homogeneous granitoids, may be linked to the continuous mixing of the S-type and I-type magmas. Phosphorus-rich and aluminium-rich magma batches, in the form of the crystal mush, were probably separated as pockets in the border zone between the felsic and mafic melts.

2. Formation of these magma pockets was initially dominated by the complex flow-controlled and to some extent also gravity-driven separation of early-formed zoned minerals, taking place during magma mixing processes and, subsequently, by local saturation in the border zones of growing feldspar and apatite crystals.

3 . In both textural and chemical character, the rocks described here are similar to apatite-rich cumulate enclave, earlier described from the High Tatra Mountains by Gawęda (2008). The apatite-rich rocks described here may have been the source of that enclave. The presence of apatite-rich granitoid rocks allow to suppose, that segregation processes in granitoid magmas could be important factors, especially in fluid-rich, syntectonic intrusions.

Acknowledgments This work was financially supported by Polish Ministry of Science and Higher Education grant No. N 307027837 to AG and National Science Centre (NCN) grant No. DEC-2011/01/N/ST10/ 07098 to KS. Piotr Dzierżanowski PhD and Mrs Lidia Jeżak are thanked for their help during microprobing. We are grateful to the Geological Survey of Norway which supported the LA-ICP-MS apatite analyses. Prof. Padhraig. S. Kennan (UCD, Dublin) is deeply thanked for the careful language correction and many important comments during preparation of the manuscript. The authors would like to thank Andreas Moeller and an anonymous reviewer who provided detailed and useful reviews of the manuscript as well as Desiree Grace Garriel for careful editorial handling.

Open Access This article is distributed under the terms of the Creative Commons Attribution License which permits any use, distribution, and reproduction in any medium, provided the original author(s) and the source are credited.

\section{References}

Bac-Moszaszwili M (1996) Tertiary-Quaternary uplift of the Tatra massif. Przyroda Tatrzańskiego Parku Narodowego a człowiek. Tom 1. Nauki o Ziemi. TPB, PTPNoZ Oddz. Krak., Kraków - Zakopane, pp 68-71

Bacon CR (1989) Crystallization of accessory phases in magma by local saturation adjacent to phenocrysts. Geochim Cosmochim Acta 53(3):1055-1066. doi:10.1016/0016-7037(89)90210-X

Baxter S, Feely M (2002) Magma mixing and mingling textures in granitoids: examples from the Galway Granite, Connemara, Ireland. Mineral Petrol 76:63-74

Bea F (1996) Residence of REE, Y, Th and U in granites and crustal protoliths; implications for the chemistry of crustal melts. J Petrol 37(3):521-552. doi:10.1093/petrology/37.3.521
Bea F, Montero P, Molina F (1999) Mafic precursors, peraluminous granitoids, and late lamprophyres in the Avila Batholith: a model for the generation of the Variscan batholiths in Iberia. J Geol 107:399-419. doi:10.1144/0016-764903-024

Belousova EA, Griffin WL, O'Reilly SY, Fisher NI (2002) Apatite as an indicator mineral for mineral exploration: trace element composition and their relationship to host rock type. J Geochem Explor 76:45-69. doi:10.1016/S0375-6742(02)00204-2

Blanc P, Baumer A, Cesbron F, Ohnenstetter D, Panczer G, Remond G (2000) Systematic cathodoluminescence spectral analysis on synthetic doped minerals. In: Pagel M, Barbin V, Blanc P, Ohnenstetter D (Ed) Cathodoluminescence in geosciences, Springer Verlag, Ch. 5, pp 127-160

Broska I, Uher P (2001) Whole-rock chemistry and genetic typology of West Carpathian Variscan granites. Geol Carpath 52:79-90

Broska I, Williams CT, Uher P, Konecny P, Leichman J (2004) The geochemistry of phosphorus in different granite suites of the Western Carpathians, Slovakia: the role of apatite and P-bearing feldspars. Chem Geol 205:1-15. doi:10.1016/j.chemgeo.2003.09.004

Broska I, Zahradnik L, Petrik I (2008) Origin of syenitic dike by a flowage differentiation (Modra Massif, Western Carpathians): evidence from the rock-forming and accessory mineral assemblage. Mineral Spec Pap 32:50-51

Burchart J (1972) Fission-track age determination of accessory apatite from the Tatra Mountains, Poland. Earth Planet Sci Lett 15:418-422

Burda J, Gawęda A (2009) Shear-influenced partial melting in the Western Tatra metamorphic complex: Geochemistry and geochronology. Lithos 110:373-385. doi:10.1016/j.lithos.2009.01.010

Burda J, Gawęda A, Klotzli U (2011) Magma hybridization event in the Western Tatra Mts. granitoid intrusion (S-Poland, Western Carpathians). Mineral Petrol 103:19-36. doi:10.1007/s00710-011-0150-1

Cox KG, Bell JD, Pankhurst RJ (1984) The interpretation of igneous rocks. George Allen \& Unwin, London

Dawson JB, Hinton RW (2003) Trace-element content and partitioning in calcite, dolomite and apatite in carbonatite, Phalaborwa, South Africa. Mineral Mag 67(5):921-930. doi:10.1180/ 0026461036750151

Dempster TJ, Jolivet M, Tubrett MN, Braithwaite CJR (2003) Magmatic zoning in apatite: a monitor of porosity and permeability change in granites. Contrib Mineral Petrol 145:568-577. doi:10.1007/s00410003-0471-0

Dorais MJ, Lira R, Chen Y, Tingey D (1997) Origin of biotite-apatiterich enclaves, Achala batholiths, Argentina. Contrib Mineral Petrol 130:31-46. doi:10.1007/s004100050347

Duchesne J-C, Martin H, Bagiński B, Wiszniewska J, Vander Auwera J (2010) The origin of ferroan-potasic A-type granitoids: the case of hornblende-biotite granite suite of the Mesoproterozoic Mazury complex, northeastern Poland. Can Mineral 48:947-968. doi:10.3749/canmin.48.4.947

Dymek RF, Owens BE (2001) Petrogenesis of apatite-rich rocks (nelsonites and oxide-apatite gabbronorites) associated with massif anorthosites. Econ Geol 96(4):797-815. doi:10.2113/gsecongeo.96.4.797

Eklund O, Konopelko D, Rutanen H, Fröjdö S, Shebanov AD (1998) $1.8 \mathrm{Ga}$ Svekofenian post-collisional shoshonitic magmatism in the Fennoscandian shield. Lithos 45:87-108. doi:10.1016/S00244937(98)00027-9

Gaft M, Reisfeld R, Panczer G, Boulon G, Shoval S, Champagnon B (1997) Accommodation of rare-earths and manganese by apatite. Opt Mater 8:149-156. doi:10.1016/S0925-3467(97)00042-6

Gawęda A (2001) Alaskites in the Western Tatra Mts. Imprint of early Variscan collision in the pra-continent of the Carpathians. University of Silesia publishing House, Monographic series, Katowice, p 174 (in Polish, English abstract)

Gawęda A (2008) An apatite-rich enclave in the High Tatra granite (Western Carpathians): petrological and geochronological study. Geol Carpath 59(4):295-306 
Gawęda A (2009) Enclaves in the High Tatra Granite. University of Silesia publishing House, Monographic series, Katowice: 180 pages (in Polish, English abstract)

Gawęda A, Sikorska M (2010) Magma mixing in the common Tatratype granite in the light of the textural and cathodoluminescence features - a comparison with the High Tatra-type. Mineral Spec Pap 37:79-80

Gawęda A, Szopa K (2011) The origin of magmatic layering in the High Tatra granite, Central Western Carpathians - implications for the formation of granitoid plutons. Trans R Soc Edinb Earth Environ Sci 102:1-16

Gawęda A, Włodyka R (2013) The origin of post-magmatic CaAl minerals in granite-diorite mingling zones: The Tatra granitoid intrusion, Western Carpathians. Neues $\mathrm{Jb}$ Miner Abh (in print)

Gawęda A, Doniecki T, Burda J, Kohút M (2005) The petrogenesis of quartz-diorites from the Tatra Mountains (Central Western Carpathians): an example of magma hybridisation. $\mathrm{N} \mathrm{Jb}$ Miner Abh 181 (1):95-109

Harrison TM, Watson EB (1984) The behaviour of apatite during crustal anatexis: equilibrium and kinetic consideration. Geochim Cosmochim Acta 48:1467-1477

Hibbard MJ (1991) Textural anatomy of twelve magma-mixed granitoid systems. In: Didier J, Barbarin B (eds) Enclaves and granite petrology. Elsevier, Amsterdam, pp 431-444

Irvine TN (1982) terminology for latered intrusions. J Petrol 23:127-162

Jaroszewski W (1965) Geological structure of the upper part of the Kościeliska Valley in the Tatra Mountains. Acta Geol Pol 15 (4):1-165 (in Polish, English abstract)

Kohut M, Janak M (1994) Granitoids of the Tatra Mts., Western Carpathians: field relations and petrogenetic implications. Geol Carpath 45:301-311

Kohut M, Sherlock SC (2003) Laser microprobe ${ }^{40} \mathrm{Ar}-{ }^{39} \mathrm{Ar}$ analysis of pseudotachylyte and host-rocks from the Tatra Mountains, Slovakia: evidence for late Palaeogene seismic/tectonic activity. Terra Nova 15(6):417-424
Lavaure S, Sawyer EW (2011) Sourse of biotite in Wuluma Pluton: replacement of ferromagnesian phases and disaggregation of enclaves and schlieren. Lithos 125:757-780

London D, Wolf MB, Morgan VIGB, Garrido MG (1999) Experimental silicate-phosphate equilibria in peraluminous granitic magma, with a case study of the Alburquerque batholith at Tres Arroyos, Badajoz, Spain. J Petrol 40(1):215-240

Morozewicz K (1914) Über die Tatragranite. N Jhb Miner Geol Paläont 39:289-345

Pearce JA, Harris NBW, Tindle AG (1984) Trace elements discrimination diagram for the tectonic interpretation of granitic rocks. J Petrol 25(4):956-983

Peccerillo A, Taylor SR (1976) Geochemistry of Eocene calc-alkaline volcanic rocks from the Kastamonu area, northern Turkey. Contrib Miner Petrol 58:63-81

Prowatke S, Klemme S (2006) Trace element partitioning between apatite and silicate melt. Geochim Cosmochim Acta 70:4513-4527

Rollinson H (1993) Using geochemical data: Evaluation, presentation, interpretation. Longman, London, p 352

Sha L-K, Chappell BW (1999) Apatite chemical composition, determined by electron microprobe and laser-ablation inductively coupled plasma mass spectrometry, as a probe into granite petrogenesis. Geochim Cosmochim Acta 63(22):3861-3881. doi:10.1016/S00167037(99)00210-0

Sun SS, McDonough WF (1989) Chemical and isotopical systematics of oceanic basalts: implications for mantle composition and processes. Magmatism in the Oceanic Basins. Geol Soc Spec Publ 42:313-345

Vernon RH, Paterson SR (2008) Mesoscopic structures resulting from crystal accumulation and melt movement in granites. T Roy Soc Edin-Earth 97:369-381

Watson EB, Capobianco CJ (1981) Phosphorus and rare earth elements in felsic magmas: an assesment of the role of apatite. Geochim Cosmochim Acta 45:2349-2358

Wolf MB, London D (1994) Apatite dissolution into peraluminous haplogranitic melts: an experimental study of solubilities and mechanisms. Geochim Cosmochim Acta 58:4127-4145 